Portland State University

PDXScholar

1982

\title{
The geology of the Floras Creek area, Curry County, Oregon
}

Jon Dudley Bounds

Portland State University

Follow this and additional works at: https://pdxscholar.library.pdx.edu/open_access_etds

Part of the Geology Commons, and the Stratigraphy Commons Let us know how access to this document benefits you.

Recommended Citation

Bounds, Jon Dudley, "The geology of the Floras Creek area, Curry County, Oregon" (1982). Dissertations and Theses. Paper 3253.

https://doi.org/10.15760/etd.3247

This Thesis is brought to you for free and open access. It has been accepted for inclusion in Dissertations and Theses by an authorized administrator of PDXScholar. Please contact us if we can make this document more accessible: pdxscholar@pdx.edu. 
AN ABSTRACT OF THE THESIS OF Jon Dudley Bounds for the Master of Science in Geology presented December 14, 1982.

Title: The Geology of the Floras Creek area, Curry County, Oregon.

APPROVED BY MEMBERS OF THE THESIS COMMITTEE:

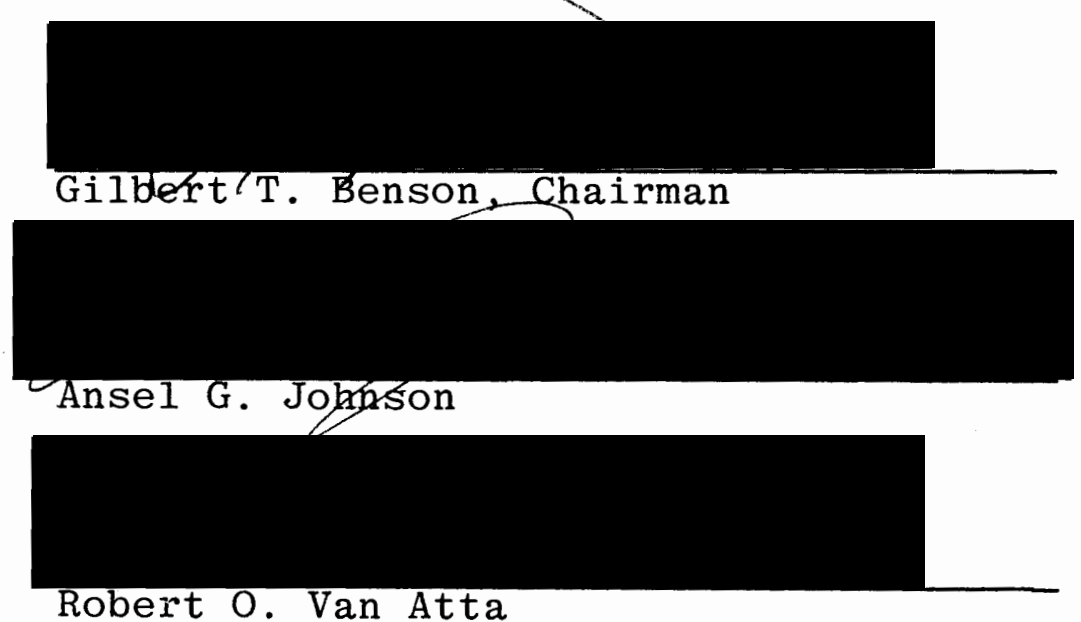

The Floras Creek area, east of the town of Langlois, near the southwest Oregon coast, includes Colebrooke Schist (a klippe of metamorphosed pelitic sediments of Jurassic age), Jurassic Otter Point Formation (a melange complex), and lower the middle Eocene Roseburg and Lookingglass Formations, part of a sandstone-shale sequence occurring more extensively in other areas. The Colebrooke Schist occurs in the south-central part of the area, bounded on the Otter Point and Roseburg. The Lookingglass is exposed as a small (1.5 sq. $\mathrm{km})$ block in the north-north-west part 
of the area. Two major structural trends are found in the Floras Creek area; an older Mesozoic east-west normal fault trend which is truncated by younger serpentinitefilled, north-south shear zones. The younger fault trend was active into the Tertiary as the faults cut the Eocene. Detrital modal analyses of sandstones suggest that the Otter Point is related to the coeval Dothan Formation of the interior Klamath Mountains, in the same way that the Franciscan is related to the Great Valley sequence in California. The detrital modal analysis indicates that the Otter Point is trench-slope deposited sediments as is the Franciscan and the Dothan is forearc basin deposits similar to the Great Valley. 


\title{
THE GEOLOGY OF THE
}

FLORAS CREEK AREA, CURRY COUNTY, OREGON

\author{
by
}

JON DUDLEY BOUNDS

A thesis submitted in partial fulfillment of the requirements for the degree of

MASTER OF SCIENCE

in

GEOLOGY

Portland State University 
TO THE OFFICE OF GRADUATE STUDIES AND RESEARCH:

The members of the Committee approve the thesis of Jon Dudley Bounds presented on December 14, 1982.

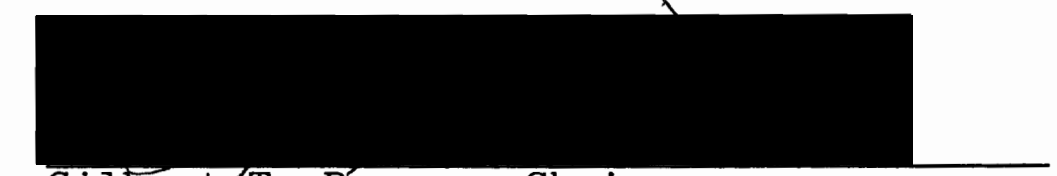

Gilbert'T. Benson, Chairman

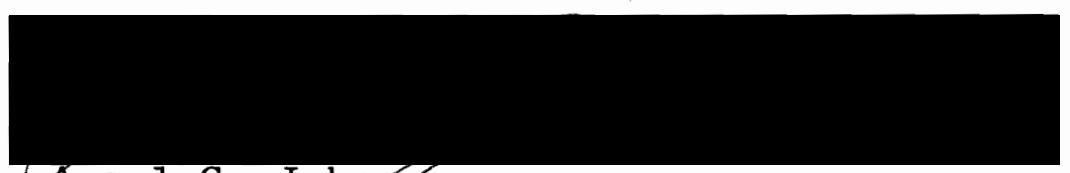

CAnsel G. Johnson

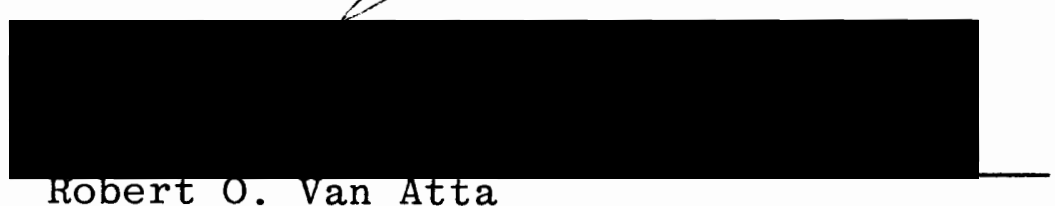

APPROVED :

Gilbert Tenson, Chairman, Department of Geology

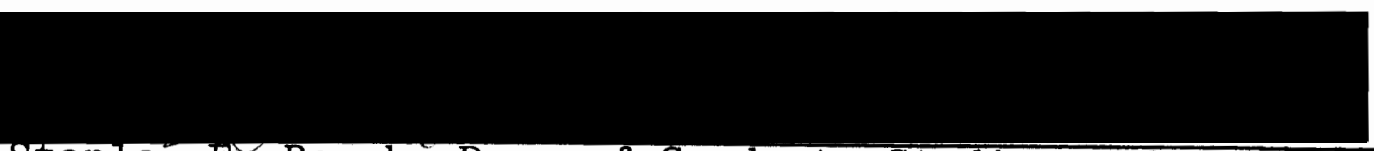

Stanley E: Rauch, Dean of Graduate Studies and Research 


\section{ACKNOWLEDGMENTS}

I wish to thank several people who have helped and encouraged me in the formulation of my thesis. To my thesis advisor, Dr. G. T. Benson, I give special thanks for help in initiating and guiding me through research, field work, analysis, and writing of this study. I also want to thank the members of my thesis committee, Dr. Ansel Johnson, Dr. Robert Van Atta and Dr. Daniel Sheans, for their constructive criticism and valuable suggestions.

Special thanks are due to Fred Gullixson, for his encouragement, companionship, access to data from his study, and many hours of technical discussions.

Thanks are also due to Ben Sprouse, U.S.B.L.M. geologist for loaned aerial photographs of the study area, to Sigma Xi, the Scientific Research Society of North America, for financial support, and to Karen wilson who typed the final manuscript.

The enduring support, encouragement, and love of my family provided me with motivation during this study. The love and affection of my wife Nancy has been both an inspiration and guide for me. She has given me support in all phases of this study and has aided me in writing of this thesis. This study is dedicated to her with all my love. 
TABLE OF CONTENTS

PAGE

ACKNOWLEDGMENTS

iii

LIST OF TABLES . . . . . . . . . . . . . . . . vi vi

LIST OF FIG URES . . . . . . . . . . . . . . . . . vii

LIST OF PLATES . . . . . . . . . . . . . . . . . ix

INTROD UCTION . . . . . . . . . . . . . . . . . . 1

Location and Accessibility . . . . . . . . 1

Purpose . . . . . . . . . . . . . . . 1

Previous Work . . . . . . . . . . . 1

ROCK UNITS . . . . . . . . . . . . . . . . . 7

Mesozoic Rock Units . . . . . . . . . . 7

Colebrooke Schist . . . . . . . . 7

Otter Point Formation . . . . . . . 9

Matrix . . . . . . . . . . 11

Native Blocks . . . . . . . . 12

Thin Section Petrography... . 15

Exotic Blocks . . . . . . . . . 15

Metabasalt ......... 15

Glaucophane Schist . . . . . 19

Radiolarian Chert . . . . . 24

Tertiary Rock Units . . . . . . . . . 27

Roseburg Formation . . . . . . . 27

Lookingglass Formation . . . . . 28 
PAGE

DETRITAL MODAL ANALYSIS OF SANDSTONE .

QFL Diagrams

QmFLt Diagrams

QpLvLs Diagrams

Discussion of Modal Analysis . . . . . . • .

North-South Trending Structure . • • • • 48

East-West Trending Structure . . . . . . .

Internal structure . . . . . . . . . . 50

Discussion . . . . . . . . . . . . . . 50

CONCLUSIONS

What is the Otter Point Formation? . . . . .

REFERENCES CITED • • • • • • • • • • • • • • • • • 58

APPENDIX A . . . . . . . . . . . . . . . . . 61

APPENDIX B . . . . . . . . . . . . . . . . . . . 74 


\section{LIST OF TABLES}

TABLE

PAGE

I. Definition of Grain Populations

for Triangular Diagrams . . . . . . . . . 33

II. Sandstone Point Count Data . . . . . . . . . 34

III. Grain Parameters and Populations Plotted

on Triangular Diagrams . . . . . . . . . . 35 


\section{LIST OF FIGURES}

FIGURE

PAGE

1 Index Map Showing Location of the Floras Creek area . . . . . . . . . . . . 2

2 Correlation Chart . . . . . . . . . . . . 44

3 Geologic Sketch Map of the Floras

Creek Study area . . . . . . . . . . . . 10

4 Photomicrograph of Native Block Sandstone . . . 13

5 Photomicrograph of Native Block Conglomerate • . 14

6 Photomicrograph of Type I Basalt . . . . . . . . 17

7 Photomicrograph of Type II Basalt . . . . . . . . 18

8 Photomicrograph of Glaucophane Schist (X-nic) . 21

9 Photomicrograph of Garnet Porphyroblast (ppl) - 22

10 Photomicrograph of Garnet Porphyroblast (X-nic) 23

11 Photomicrograph of Radiolarian Chert . . . . . . 25

12 Photomicrograph of Radiolaria within Chert . . . 26

13 Photomicrograph of Typical Roseburg Formation Sandstone . . . . . . . . . . . 29

14. Photomicrograph of Typical Lookingglass

Formation Sandstone . . . . . . . . . . 31

15 Q F L Triangular Diagram . . . . . . . . . . . 37

16 Qm F Lt Triangular Diagram . . . . . . . . . . . 39

17 Qp Lv Ls Triangular Diagram . . . . . . . . . . 41

18 Qm P K Triangular Diagram . . . . . . . . . . . 42 
19 Schematic Cross-section of Typical Arc-Trench System ........... 45

20 Cartoon Map View of Subduction Zone . . . . . 47

21 Schematic Cross-section of Typical Flow Melange . . . . . . . . . . . 54

22 Index Map of the Floras Creek Area Showing Areas Mapped on the Basis of Aerial Photo Interpretation . . . . . . . . . . 75 


\section{LIST OF PLATES}

PLATE

PAGE

I. Geologic Map of the Floras Creek Area . . in pocket

II. Geologic Cross-sections $A-A^{\prime}$ and $B^{\prime} B^{\prime}$. . in pocket 


\section{INTRODUCTION}

\section{LOCATION AND ACCESSIBILITY}

This study covers an area of approximately 73 square kilometers (28 square miles) in the northern half of the Langlois quadrangle, Curry County, Oregon (Figure 1). The town of Langlois is located at the western edge of the area, and Port Orford is about $32 \mathrm{~km}(20 \mathrm{mi})$ to the south. This area straddles the boundary between the Klamath Mountains province, which consists of Mesozoic metamorphosed sedimentary and volcanic rocks to the south, and the Coast Range province, Tertiary sedimentary and volcanic rocks to the north.

A paved county road from Langlois, along Floras Creek to the eastern boundary of the study area, provides the primary access. Another paved county road from Langlois crosses the northwest corner of the area, and an unpaved road runs from the Floras Creek Road south to Edson Butte (Plate I). In general, access is poor, and so are exposures.

\section{PURPOSE}

This study is an attempt to define the stratigraphic and structural relationships between the Otter Point Formation, the Colebrooke Schist, and the Roseburg and 


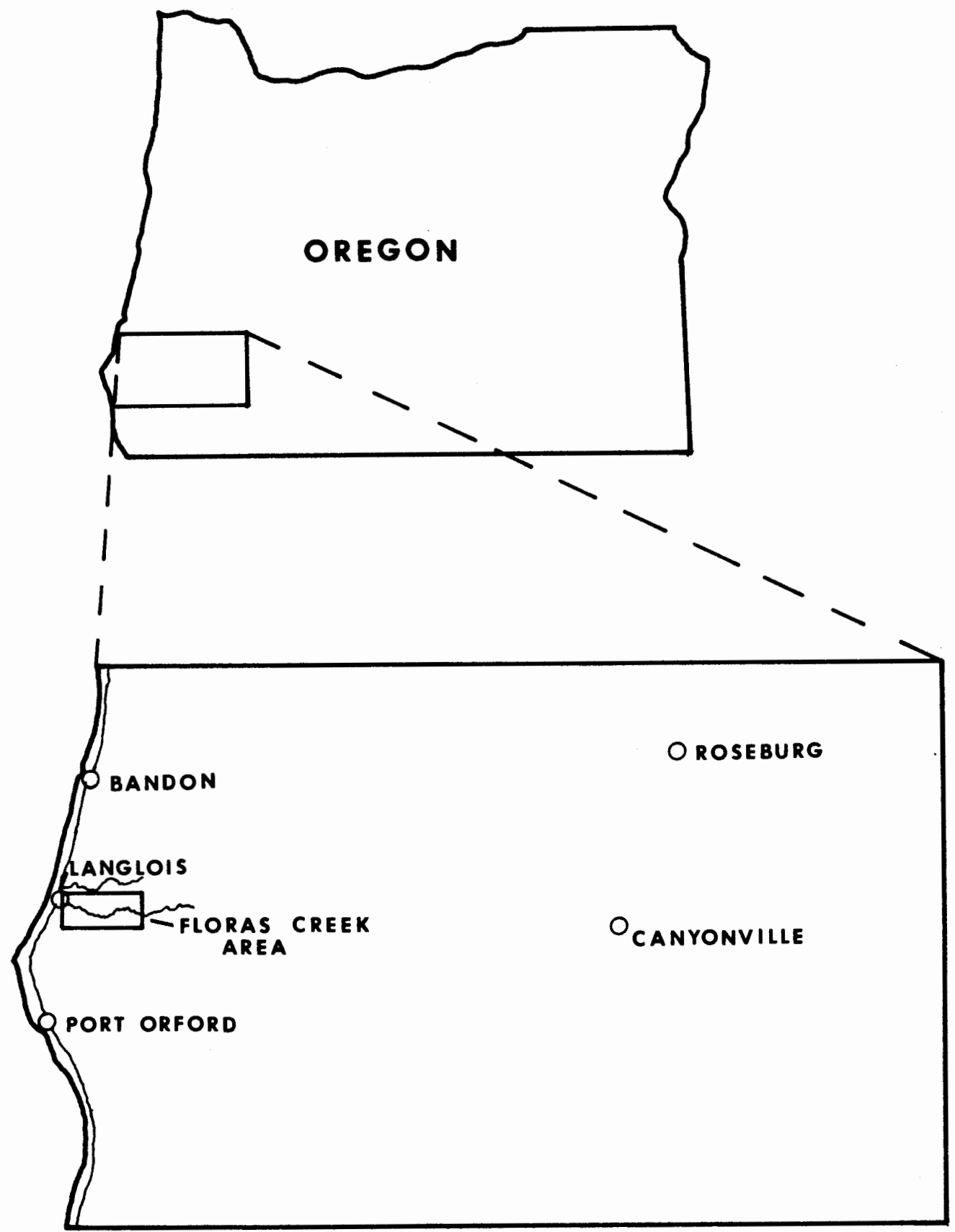

Figure 1. Index map showing the location of the Floras Creek area. 
Lookingglass Formations (Figure 2). In addition it begins to explore, on the basis of sandstone petrology, the regional significance of the Otter Point in relation to coeval units in the Klamath Mountains and compared to the Franciscan and Great Valley sequences in California.

\section{PREVIOUS WORK}

In the United States Geological Survey Port Orford Folio, Diller (1903) assigned unmetamorphosed pre-Tertiary rocks in the Floras Creek area to the Myrtle Formation. Diller's Myrtle Formation was named for lower Cretaceous rocks exposed south of Roseburg in Douglas County, Oregon. The "Myrtle Formation" along the southwestern Oregon coast is separated from the type Myrtle by Tertiary rocks of the Oregon Coast Range. Imlay and others (1959) raised the type Myrtle to group status and subdivided it into the Riddle and Days Creek Formations. The rocks mapped as belonging to the Myrtle Formation near the coast by Diller (1903), contain the same upper Jurassic and lower Cretaceous fossils, but are lithologically different from the type Myrtle (Lent, 1969). Thus similarity in ages resulted in rocks in the Port Orford and Gold Beach area being mapped as members of the Myrtle Group in spite of lithologic differences (Lent, 1969). Koch (1966) divided the coastal Myrtle Group into uppermost Jurassic Otter Point Formation and lower Cretaceous Humbug Mountain Conglomerate and Rocky Point Formation based on faunal and lithologic variations 


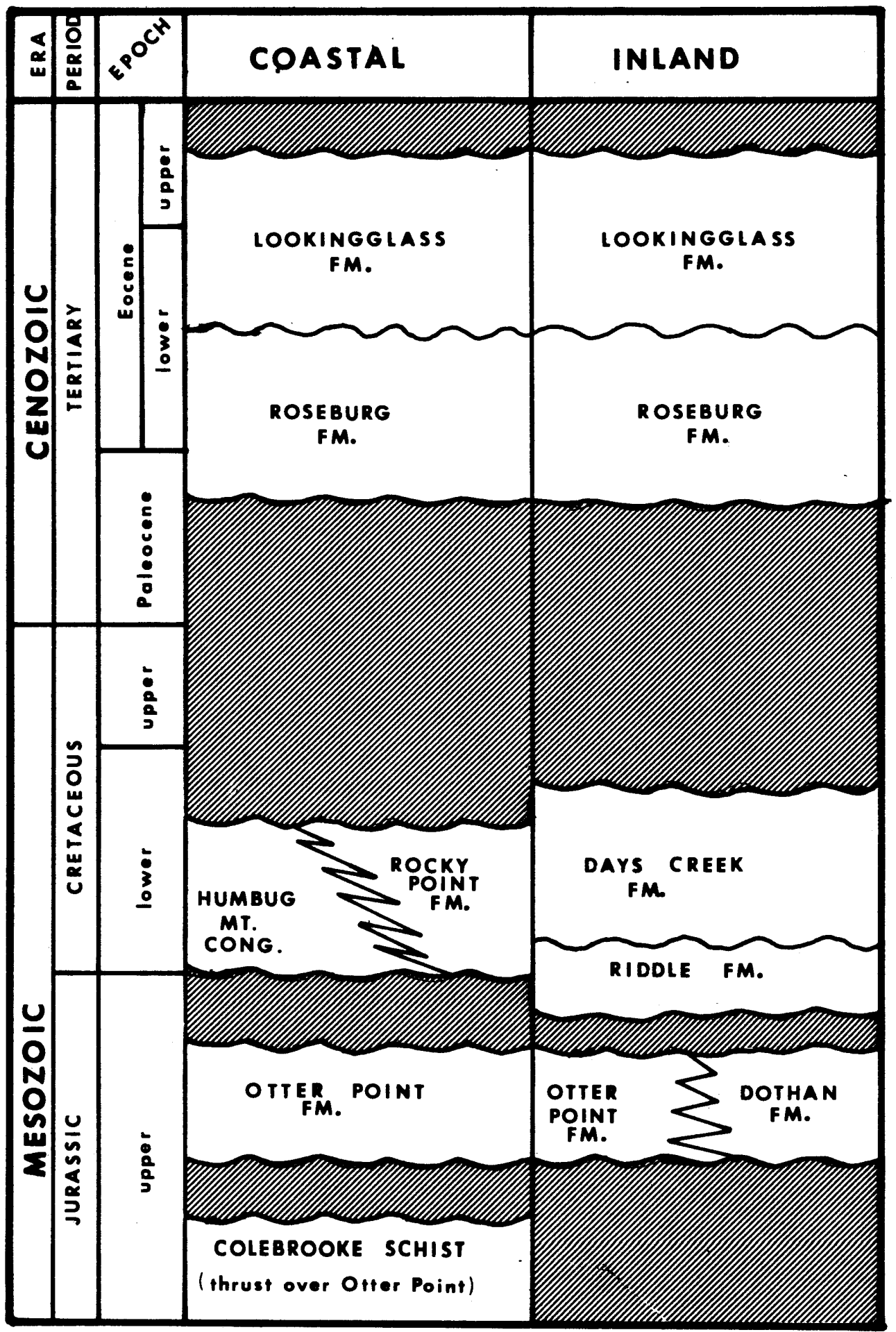

Figure 2. Stratigraphic correlation diagram of formations in and near the thesis study area. (after Baldwin, 1974) 
in a seemingly homogeneous eugeosynclinal suite, Koch correlated the coastal uppermost Jurassic and lower Cretaceous formations with the inland Riddle and Days Creek Formations. However, the earliest Cretaceous age of the Riddle Formation as suggested by Jones (1969), and an apparent major unconformity between the coastal uppermost Jurassic and lower Cretaceous require that only the lower Cretaceous (i.e. Humbug Mountain Conglomerate and Rocky Point Formation) be correlated with the Myrtle Group.

The Dothan Formation was named by Diller (1907) for a locality on Cow Creek, in Douglas County, $64 \mathrm{~km}$ (40 mi) east of the study area. Diller believed that the formation extended southwest to the coast near the California border, an interpretation supported by Wells and Walker (1953) and Ramp (1964). For many years it appeared that Dothan rocks extend directly into the Franciscan assemblage, a pattern which has produced a long-standing state-line stratigraphic boundary problem.

Wells and Walker (1953) mapped four distinct zones within the Dothan Formation. The westernmost, which is in fault contact with an ophiolite mass, is predominantly thinly stratified mudstone and siltstone with rare sandstone units, and volcanic rocks and chert at the top; zone 2 is sheared black mudstone with local calcareous nodules and thin conglomerate; zone 3 is massive cliff-forming graywacke; and the most easterly zone 4 is characterized by interstratified mudstone and sandstone with sandstone 
increasing in abundance to the east. Along the coast, just north of the California border, the Dothan Formation was separated into two members by Widmier (1962). The eastern Winchuck Member, consists of black mudstone. The coastal Macklyn Member has a higher percentage of graywacke, volcanics, and chert. In addition, the Macklyn Member is much more highly sheared than the Winchuck Member. The Winchuck Member possibly corresponds to the zones 1 and 2 of Wells and Walker (1953). The Macklyn Member probably does not correspond to any of these zones on the basis of its predominantly sandstone composition. 


\section{ROCK UNITS}

\section{MESOZOIC ROCK UNITS}

\section{COLEBROOKE SCHIST}

In the south-central quarter of the study area, metamorphic rocks occur in what has been mapped by previous workers (Brownfield, 1969) as a small klippe (19.4 sq. km) of the Colebrooke Schist, the major bodv of which is present $40 \mathrm{~km}$ to the south of the study area (Plate I).

In the type section to the south as described by Coleman (1972), the Colebrooke Schist consists of primarily metamorphosed pelitic sediments with minor metabasalt. Metamorphosed graded beds of sandstone and shale, 2-8 $\mathrm{cm}$ in thickness, are predominant. The mineral assemblages of pelitic and basaltic rocks reflect metamorphism intermediate between blueschist and greenschist facies.

The Colebrooke klippe in the study area appears to be somewhat different from the type Colebrooke Schist. The most noticeable difference between the type Colebrooke Schist and the northern klippe is the occurrence of thick beds of metagraywacke in the northern klippe while in the type Colebrooke, to the south, thick beds of metagraywacke are notably absent. In fact some northern Colebrooke metagraywacke outcrops have the same color and appearance as graywacke outcrops of the Otter Point Formation. Also, within this metagraywacke occur conglomerate lenses of very 
well-sorted chert and basalt pebbles of $3-5 \mathrm{~mm}$ in diameter, which look identical to conglomerate lenses in Otter Point graywacke outcrops.

The northern Colebrooke klippe does resemble the type Colebrooke in degree of metamorphism. Mica schist is probably the most common higher grade metamorphic rock in the klippe. In outcrop examination, the mica schist looks identical to mica schist in the type Colebrooke outcrops. Another similarity between the northern klippe and the Otter Point Formation, and therefore a difference between this klippe and the type Colebrooke Schist, is the general appearance of the units in aerial photographs. The Colebrooke Schist to the south appears as a rugged, high relief terrain, whereas the northern Colebrooke and the Otter Point both have more rounded and hummocky topography with relatively moderate relief.

Along the north boundary of the northern klippe, the contact of the Colebrooke Schist with the Roseburg Formation looks like, and has been mapped (Brownfield, 1969) as, a thrust with the Colebrooke Schist forming the upper plate. Close examination has led this writer to the interpretation that the Colebrooke Schist northeast of White Mountain, in sections $3,4,5,8,9,10$, and $11, T .30 S, R .14 W$ (Plate I), is involved in a large soil and rock creep or earth flow. This conclusion is based, first on interpretation of aerial photos, and second on observation in the field of 
the totally chaotic nature of the material, trees inclined at high angles downslope, and abundant moisture within the material. Since Coleman (1972) placed the age of tectonic emplacement of the Colebrooke Schist as late Cretaceous, the thrust contact between the Colebrooke and the Roseburg Formation is more logically interpreted as an earth flow deposit of Colebrooke material overlying the RoseburgColebrooke contact.

\section{OTTER POINT FORMATION}

Description of the Otter Point Formation was summarized by Koch (1966) as follows:

The type section of Otter Point, in the $\mathrm{NE} 1 / 4$ of Sec. 13, T. 36S., R. 15W., Gold Beach Quadrangle, consists of repetitiously interstratified, dark gray to black, thin mudstone and graded sandstone, some pebbly mudstone, and several thin beds of andesitic and keratophyric volcanic breccia. The sandstone has convolute bedding, fine crossstratification (amplitude up to $3 \mathrm{~cm}$ ), and contortions, as well as groove, flute, and load sole marks. Some of the mudstone contains abundant coalified plant debris and numerous small lenses and nodules of very argillaceous limestone.

The Otter Point in the study area consists of a matrix of sheared mudstone, argillite, and clay, containing scattered, highly sheared blocks of sandstone, metavolcanic greenstone, radiolarian chert, and glaucophane schist. Otter Point underlies about forty-five percent of the study area (Plate I and Figure 3), but exposures are very poor. These rocks form part of a melange (Hsu, 1968) that is widespread in the coastal part of the Klamath Mountains of Oregon. 


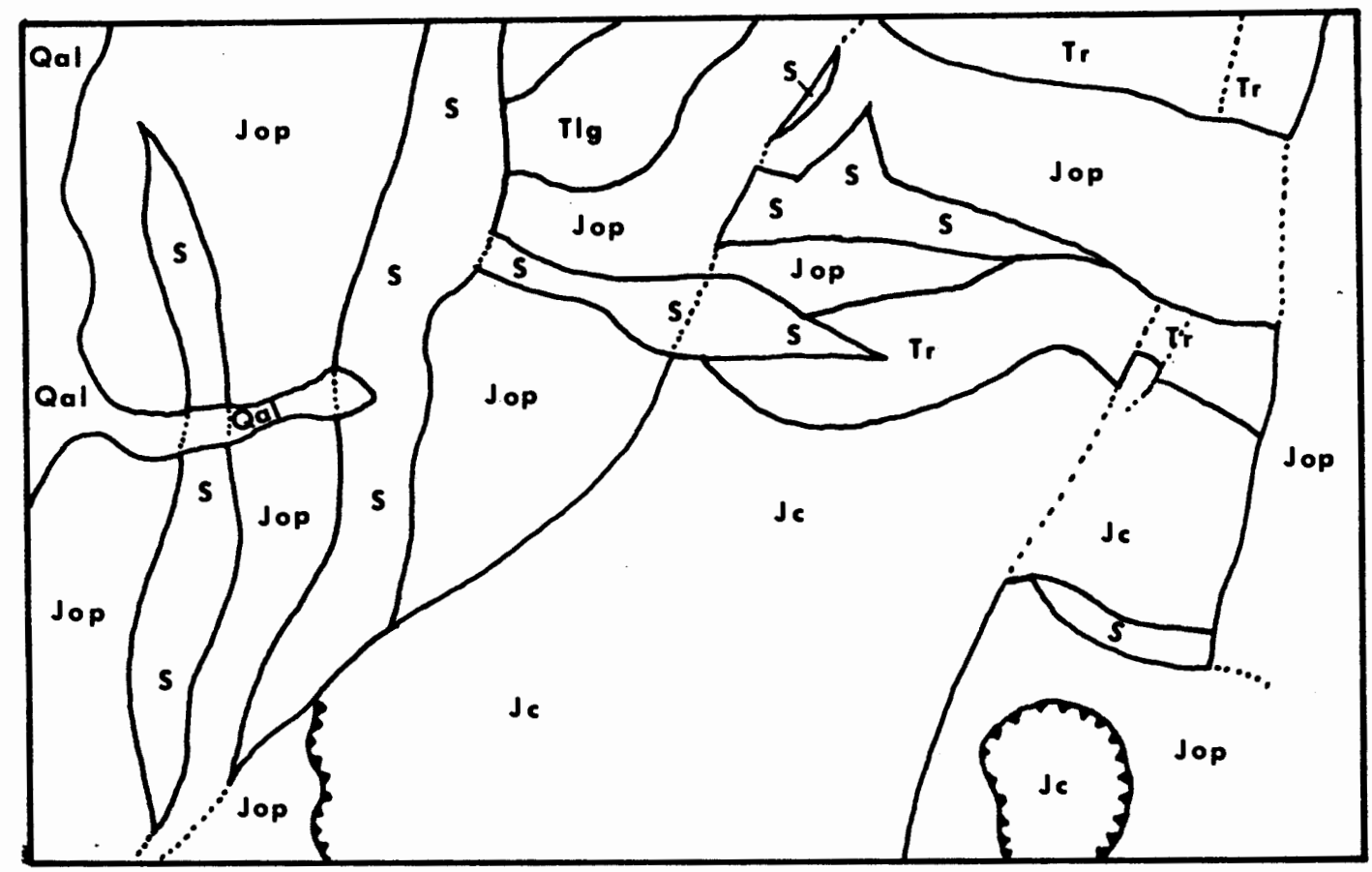

Figure 3. Jeologic sketch map of the Floras Creek study area. Jc - Colebrooke Schist, Jop - Otter Point, Tr - Roseburg, Tlg - Lookingglass, Qal - Quaternary alluvium, S - Serpentinite. 
For convenience, the Otter Point rock types will be differentiated in this study as matrix, native blocks (sandstone blocks), and exotic blocks (metabasalt, glaucophane schist, and radiolarian chert). This subdivision has been used previously by Hsu (1968) in studies of the Franciscan Melange of Northern California. Native blocks are not distinguished in mapping, as the contacts are commonly gradational, blurred by weathering, or covered. The exotic blocks, however, are mapped with little difficulty. These blocks tend to stand in fairly high relief against the matrix due to their resistance to weathering. The exotic blocks make up about five percent of the formation.

\section{MATR IX}

The bulk of the Otter Point Formation is composed of rock referred to in this paper as matrix. The only exposures of the matrix are found in road cuts, excavations, and rarely, around large native and exotic blocks.

In fresh exposures, the matrix consists of thin discontinuous beds of argillite separated by pervasively sheared mudstone or claystone. Where fresh, the matrix is dark gray to black and weathers to blue-gray. Thin sandstone laminae are present in some exposures. Veins and stringers of secondary quartz and calcite commonly crosscut the bedding. More weathered exposures of the matrix are characterized by blue-gray clay containing abundant 
angular fragments of argillite, quartz, and calcite.

\section{NATIVE BLOCKS}

After the matrix, the predominant rocks of the Otter Point Formation in the Floras Creek drainage are numerous blocks of massive lithic sandstone (graywacke) and rhythmically bedded sandstone and argillite. These blocks of sandstone occur as various sized, one to 500 meters in maximum dimension, "inclusions" within the matrix. According to many authors (e.g. Scholl and others, 1980; Connelly, 1978; Dickenson and Seely, 1979; Hsu, 1971), these blocks represent the tectonically broken sedimentary beds that accumulated depositionally within trench slope basins, and also sedimentary masses that were transferred to oceanic crust as olistostromes, which were thrust from an adjacent accreting margin.

Lines of these blocks tend to be ridge formers as they are much more resistant to erosion than the matrix. The sandstone of the native blocks is typically medium gray to green-gray, with graded bedding, pebble lenses, and clay laminae present in some outcrops. No megafossils were found in the Floras Creek study area, but ammonite fragments and a few complete Pelecypod valves, identified by the author as Buchia sp., were collected in argillite of an outcrop of bedded sandstone and argillite along Sixes River Road, approximately $8 \mathrm{~km}(5 \mathrm{mi})$ south of the study area. 


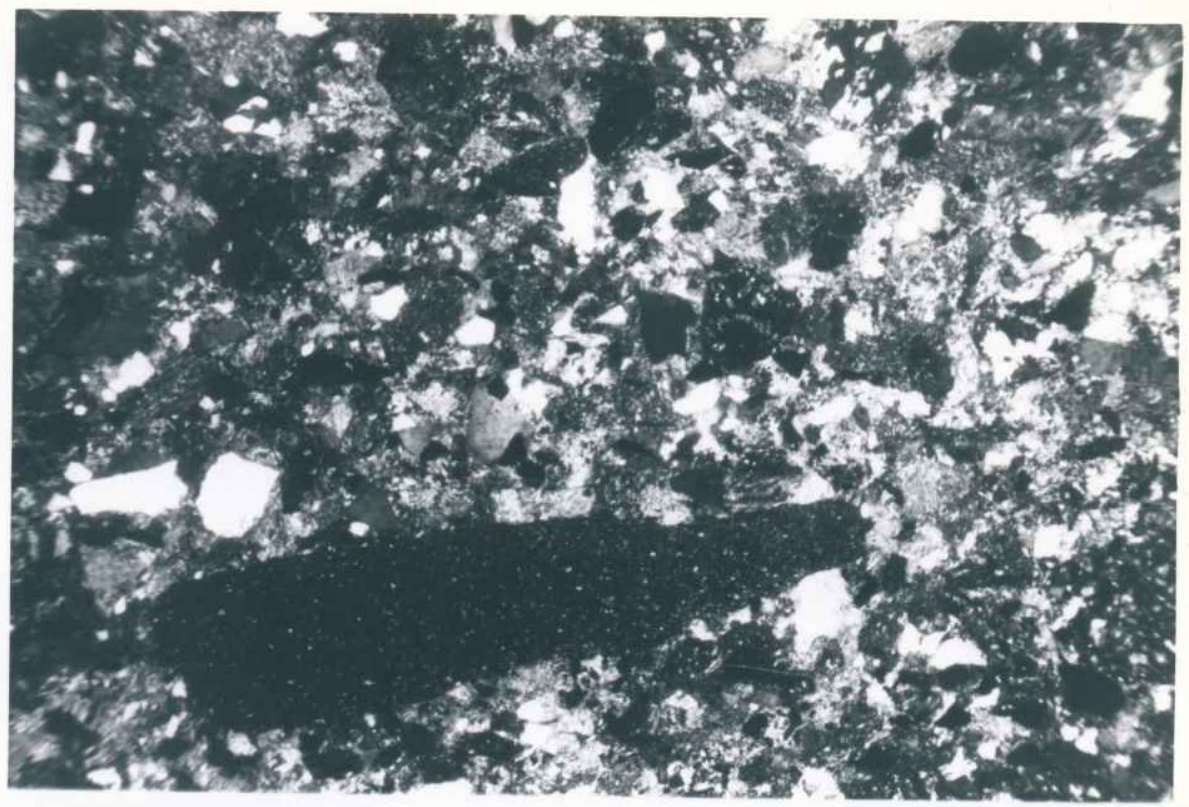

Figure 4. Photomicrograph of a typical Otter Point sandstone. Shale clast is approximately two millimeters in length (plane light). 


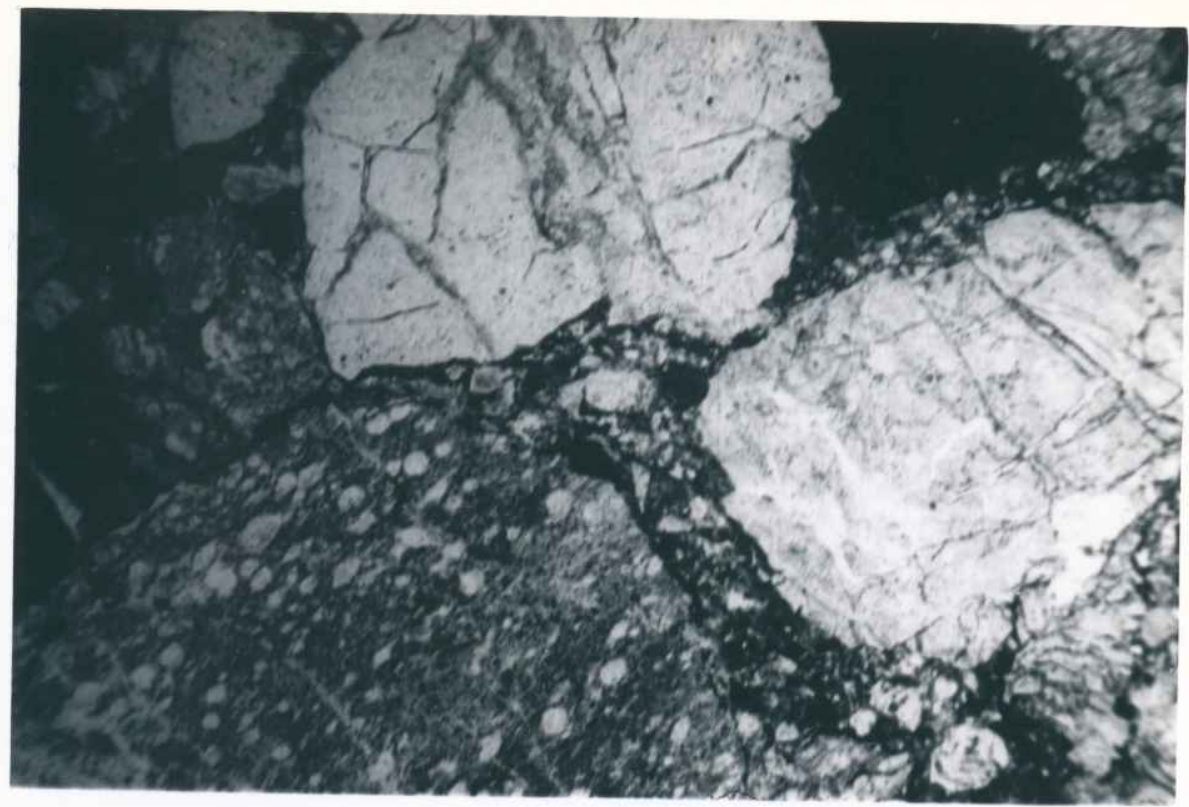

Figure 5. Photomicrograph of an Otter Point chert pebble conglomerate. Clasts are chert and about five millimeters in diameter. Note the radiolarian chert in the lower left (plane light). 
This would agree with the Jurassic/Cretaceous age assignment by Dott (1971). Minute carbonized plant fragments were also found in a few samples.

\section{Thin-section Petrography}

Quartz, plagioclase, and rock fragments are the major framework components of the sandstone in the Otter Point Formation. Trace amounts of opaques, hornblende, epidote, and sphene are also present. The main lithic fragment types are basalt, argillite (very hard and very black), phyllite, and rarely, blue schist. The sandstone matrix consists of clay with varying amounts of limonite and chlorite. Silica and clay are the cementing agents. In about $45 \%$ of the samples, the sandstone is tectonically sheared with fractures commonly filled with quartz, calcite, and chlorite (Figure 4 and Figure 5).

\section{EXOTIC BLOCKS}

"Exotic blocks" occur in the Otter Point Formation but are much less numerous than the sandstone blocks. These blocks are of metabasalt (Jopv), glaucophane schist (Jopsh), and radiolarian chert (Jopc) which crop out sporadically throughout the study area (Plate I).

\section{Metabasalt}

Stretching across the study area is a string of metabasalt blocks. These blocks generally are knob-formers and 
can be identified on aerial photographs. Field mapping and aerial photo interpretation indicate that these blocks are distributed mainly within and near large shear zones. To the north of the study area, metabasalt blocks occur in fewer numbers and seem to have no regular pattern of distribution (Gullixson, 1981).

The metabasalt is divided into two types based on thin section examination. Type I has fairly well-preserved igneous texture with the plagioclase only slightly altered and ferro-magnesian minerals partially replaced by chlorite. Type II is severely altered, highly sheared, and has very poor preservation of the primary igneous texture. Also, in type II metabasalt, glaucophane is present as overgrowths on hornblende.

The type I metabasalt is massive, porphyritic, is sub-ophitic in texture and is only slightly sheared (Figure 6). Plagioclase $(\mathrm{An}-50)$, hornblende and hypersthene are the major minerals while the accessory minerals are chlorite, epidote, and quartz. The chlorite is found as reaction rims on hypersthene and hornblende. The hornblende is possibly secondary.

The type II metabasalt is massive and thoroughly sheared. The primary igneous texture has been almost completely lost due to severe alteration (Figure 7). The groundmass of epidote, apatite, and quartz still shows a few phenocrysts of spilitized plagioclase and hornblende 


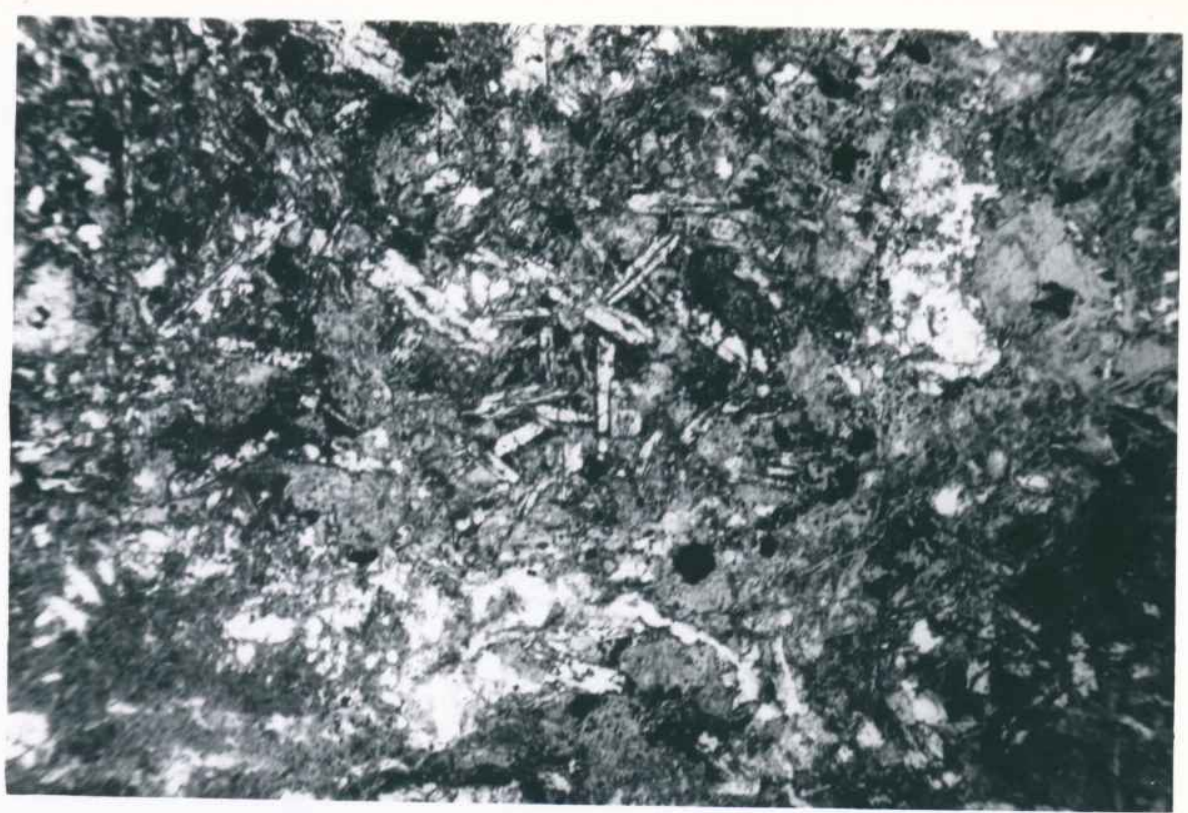

Figure 6. Photomicrograph of type I metabasalt. White - plagioclase, gray - hypersthene and chlorite. Field of view is about $5 \mathrm{~mm}$. (polarized light) 


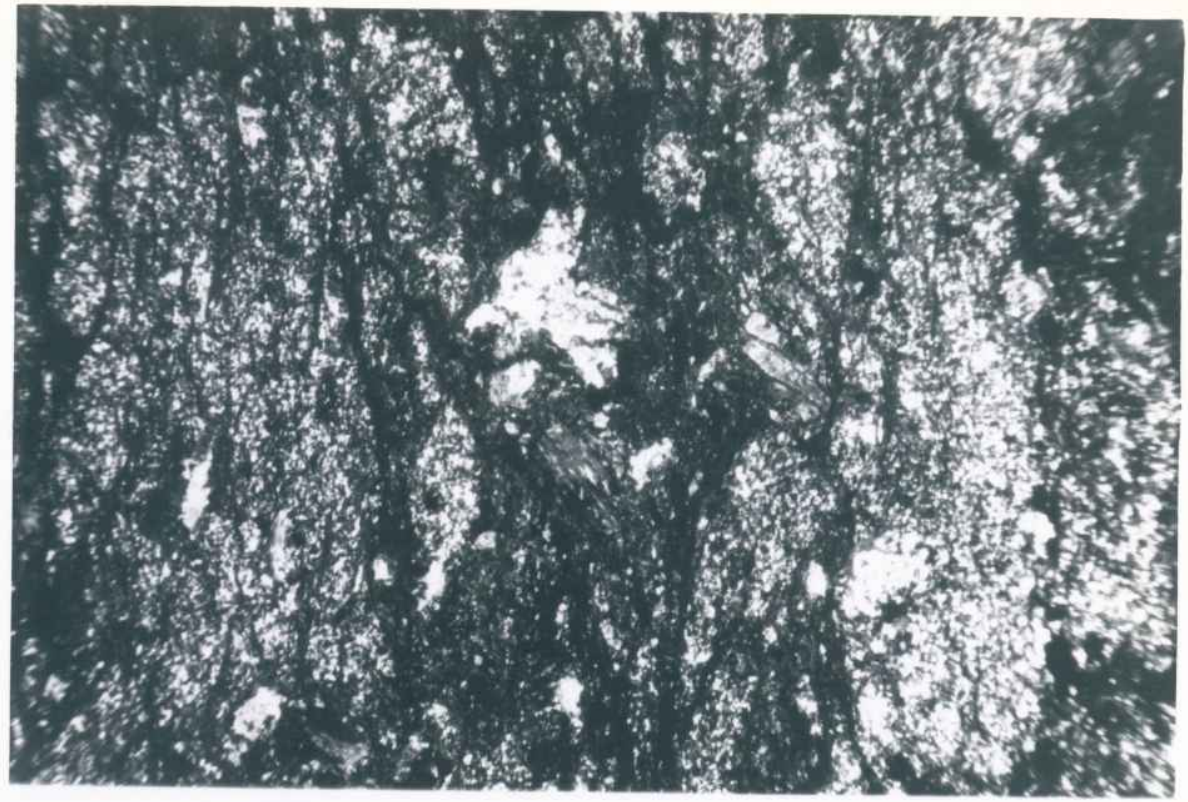

Figure 7. Photomicrograph of type II metabasalt. Note the pervasive shearing. Field of view is about $5 \mathrm{~mm}$. (plane light) 
Most of the fractures are filled with quartz and/or calcite. Extensive intergrowths of acicular apatite give a felted appearance to the groundmass. Strain twinning is characteristically exhibited by the phenocrysts of plagioclase (An15), and most of the hornblende have overgrowths of glaucophane and are partially altered to chlorite. The presence of glaucophane and apatite and the amount of shearing suggest a much higher grade of greenschist metamorphism for type II than type I metabasalts.

Pillow structures have been noted in exotic blocks in the Otter Point Formation to the south (Baldwin, 1974), but none were found in the study area. Also, no volcanic breccia was found in the area as was found in the Sixes River drainage by Lent (1969).

\section{Glaucophane Schist}

The second most abundant exotic rock type in the otter Point Formation in this study is glaucophane schist (blueschist). Outcrops varying in size from a few meters to several hundred meters in diameter cover less than $1 \%$ of the area. The glaucophane schist is also a knob-former as it is very resistant to chemical and mechanical weathering. Because this rock is very tough and dense, it is used for the construction of jetties, breakwaters, and roads when it can be found in large enough quantities to justify quarrying operations.

In outcrop, the blueschist is typically dark olive 
green to dark blue-gray in color due to a high concentration of either actinolite of sodium amphibole (glaucophane). Although compositional gneissic banding is present in some samples, a more schistose texture is commonly found. Although not always obvious in hand specimens, compositional banding is common in thin-sections. Strong lineation of elongate prismatic crystals is exhibited in all samples. Except for those samples that exhibit well developed gneissic structure, foliation defined by mica crystals is found in all samples.

The mineral composition of the blueschist is variable, but is characterized by the assemblage: glaucophane (crossite), actinolite, epidote group (epidote, zoisite, clinozoisite), with greater or lesser amounts of albite, quartz, chlorite, garnet (almandite ?), muscovite, and trace amounts of sphene, apatite, rutile, and lawsonite. Variations in mineral proportions are presumably due to differences in source rock type and metamorphic grade. Possible source rocks include graywacke and basalt (Gullixson, 1981).

Most samples contain porphyroblasts of garnet (Figure 8). These garnets appear euhedral in plane polarized light (Figure 9), but under crossed nicols they exhibit partial replacement by chlorite (Figure 10). This may be an indication of retrograde metamorphism as described by Coleman and Lanphere (1971) or possibly simple alteration. 


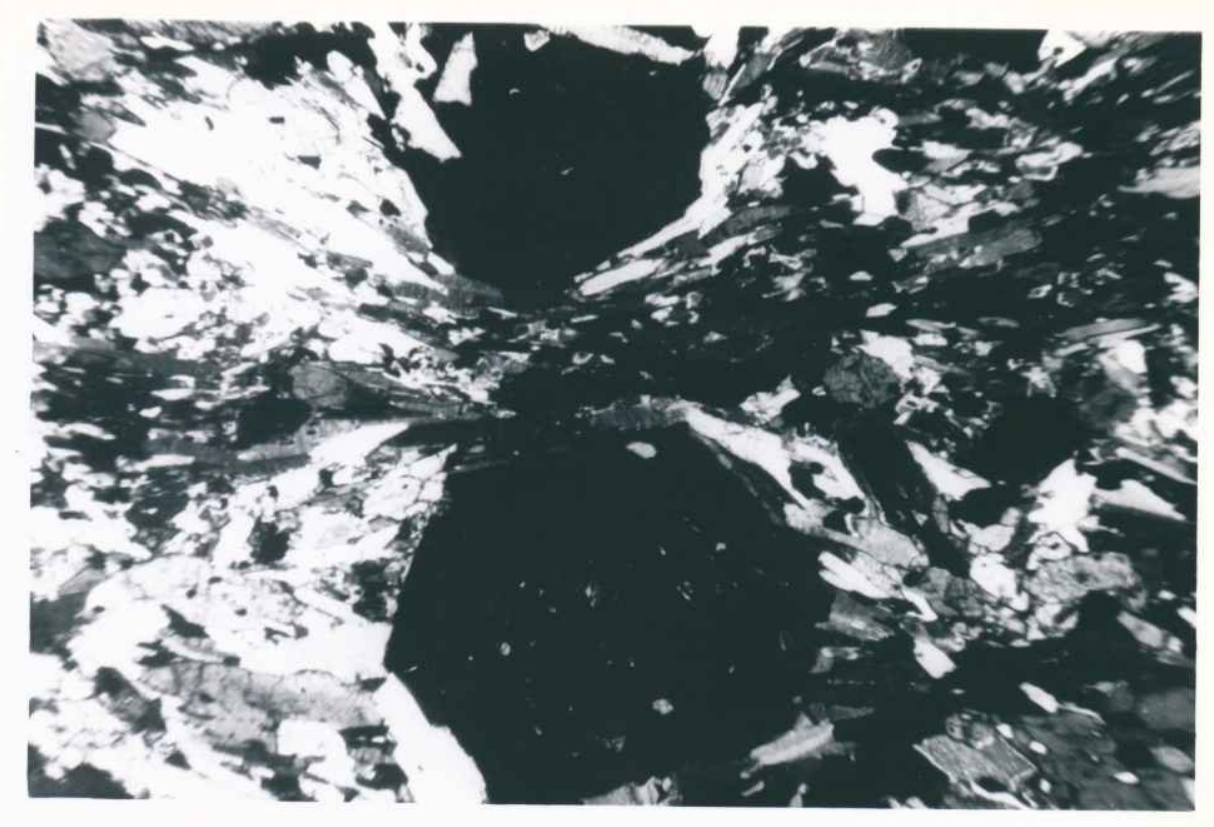

Figure 8. Otter Point glaucophane schist. Garnet porphroblasts are two millimeters in diameter (polarized light). 


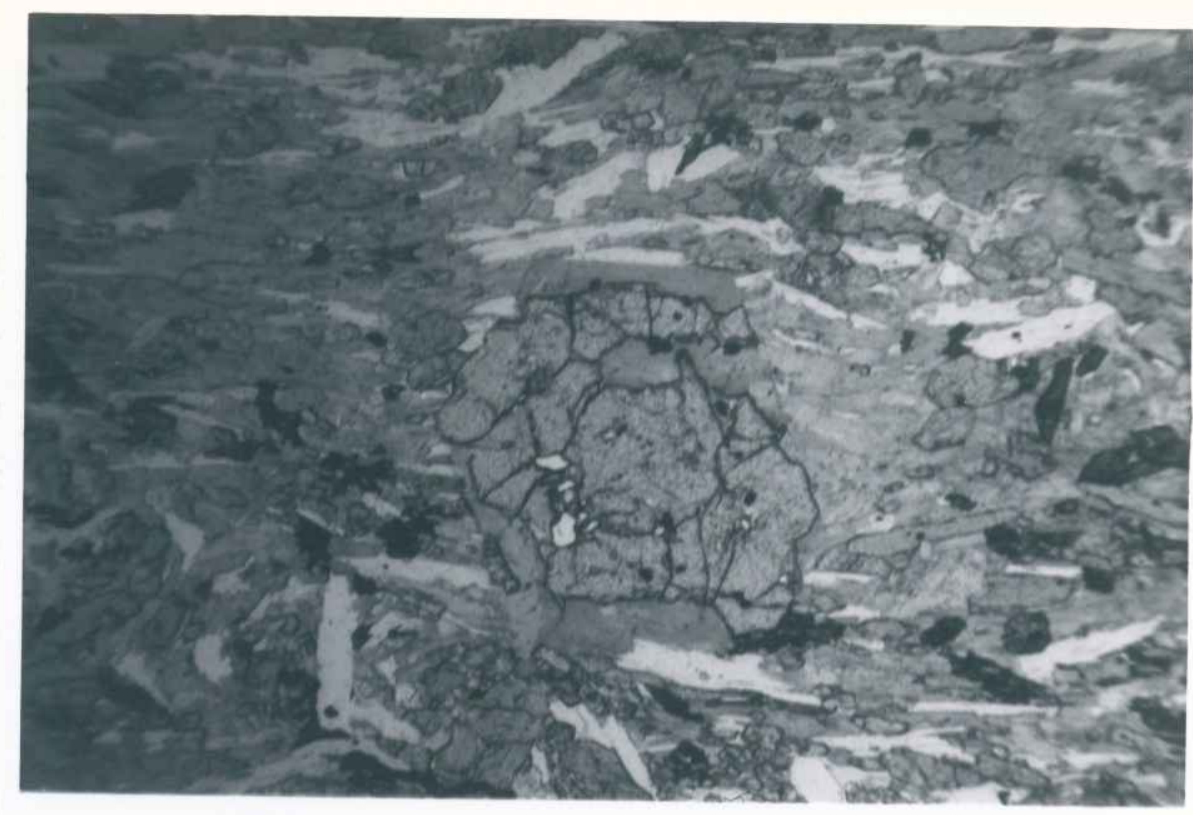

Figure 9. Garnet porphroblast in plane light. Note the chlorite alteration. 


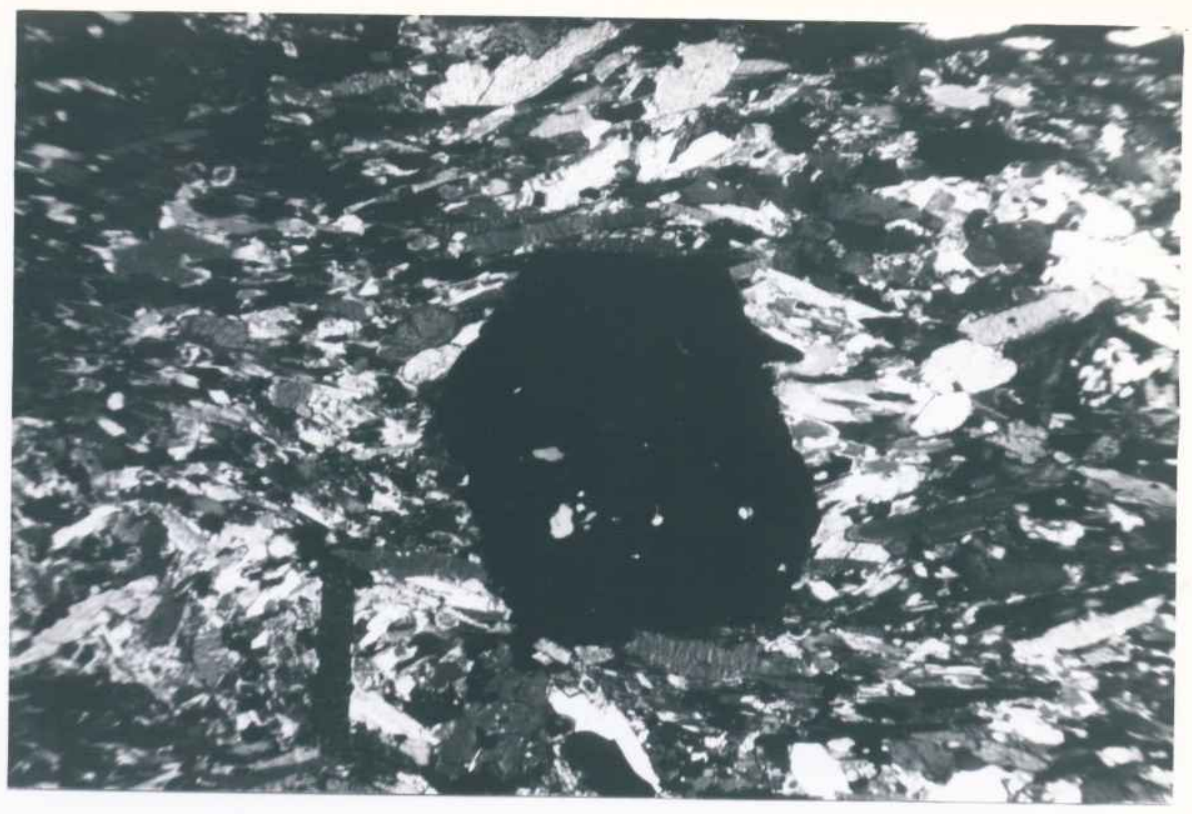

Figure 10. Euhedral garnet porphroblast within the glaucophane schist (polarized light). 
Bedded Radiolarian Chert

Small blocks of rhythmically bedded radiolarian chert are scattered throughout the Floras Creek area but they account for only a very small fraction of the exotic blocks within the formation. These blocks range in size from a few meters to a few tens of meters is diameter.

The chert is typically reddish brown (locally green or $\tan$ ) and occurs as 2-7 cm thick beds separated by thin siliceous shale or argillite interbeds or as homogeneous contorted sequences of $1-3 \mathrm{~cm}$ thick beds separated by thin shaley partings. Contorted sequences generally show chevron or kink folding with fold hinges exhibiting no noticeable thickening of fracturing.

Petrographic examination of this chert reveals replacement quartz-filled radiolaria in various stages of preservation set in very fine-grained matrix of cryptocrystalline of microcrystalline quartz. The chert is highly recrystallized and cut by abundant quartz-filled veinlets (Figure 11). Some beds exhibit laminae 1-3 mm thick which tend to have concentrations of radiolaria at the laminae boundaries.

Even though radiolaria could be found throughout the chert in various stages of preservation, only the general shapes could be discerned, mostly spheres and cones (Figure 12.). 


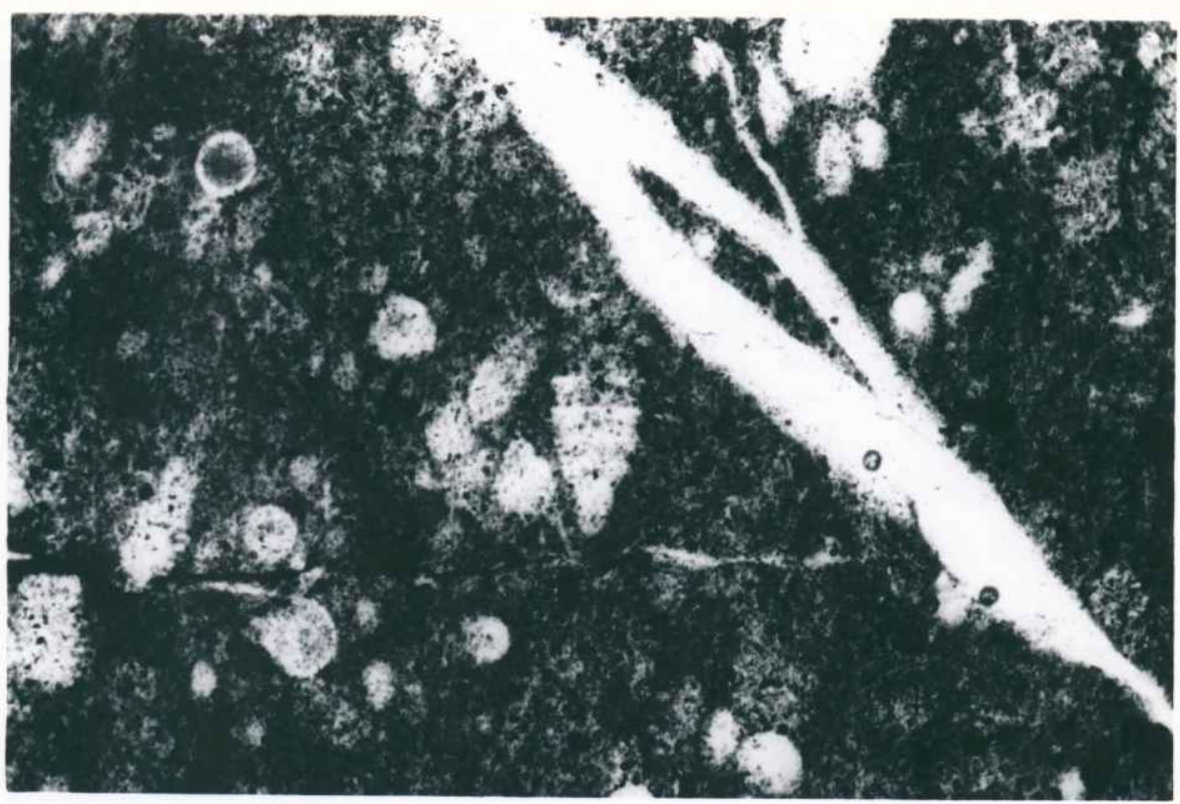

Figure 11. Typical Otter Point radiolarian chert. Field of view is approximately five millimeters. 




Figure 12. Conical and spherical radiolaria within the radiolarian chert. Field of view is about $1.5 \mathrm{~mm}$. 


\section{TERTIARY ROCK UNITS}

ROSEBURG FORMATION

Rocks of the Roseburg Formation (Plate I) make up about $60 \%$ of the Tertiary rocks within the study area. Two blocks of the Roseburg Formation are exposed in the area. The most northerly exposures are the southern tip of a large block mapped by Gullixson (1981). The other block of the formation lies in a narrow, east-west-trending strip along the northern edge of the Colebrooke Schist.

Baldwin (1974) determined the Roseburg to be early Eocene in age although he stated that with additional information, the Roseburg in the south coastal area may be separable from the eastern Roseburg into another stratigraphic unit. He based his inference on work by Dott (1962) on beds near Blacklock Point, west of the town of Langlois, Oregon, and mapping by Lent (1969) of beds along Edson Creek, which is about $5 \mathrm{~km}$ southeast of the study area. These beds were assigned by these workers to a Late Cretaceous age.

Baldwin (1974) described the typical Roseburg sedimentary rocks as follows:

Sedimentary rocks within the Roseburg Formation include thick sections of rhythmically bedded sandstone,..., and minor amounts of conglomerate and pebbly sandstone.

Within the Floras Creek area, this description does not apply. The primary rock type within the area is massive, 
fine to medium grained sandstone. Sections of rhythmically bedded sandstone and siltstone were not found in any outcrop.

Thin-section examination of the Roseburg sandstone indicates that it is massive, clay cemented volcanic litharenite. It is fine to medium grained, moderately well sorted with sub-rounded grains. The framework is made up of quartz, rock fragments, and plagioclase (Figure 13). The lithic component comprises volcanic and occasional metamorphic rock fragments (metamorphic component is primarily phyllite and rare blueschist) with the volcanic fragments being most abundant.

\section{LOOKINGGLASS FORMATION}

Rocks of the Lookingglass Formation occur on1y in an approximately 1.5 square $\mathrm{km}$ ( 0.6 square $\mathrm{mi}$ ) area in sections 31, and 32 near the Langlois Mt. Road (Plate I).

Within the study area, the Lookingglass Formation consists of massive, medium to coarse grained sandstone, channeled and cross-bedded sandstone exhibiting coarse grained, pebbly sandstone and conglomerate lenses in channel fills. The clasts of the conglomerate consist of granitic and basaltic types of igneous rocks, chert, and sandstone.

The Lookingglass Formation in the study area differs from the Roseburg Formation, locally, by being much 


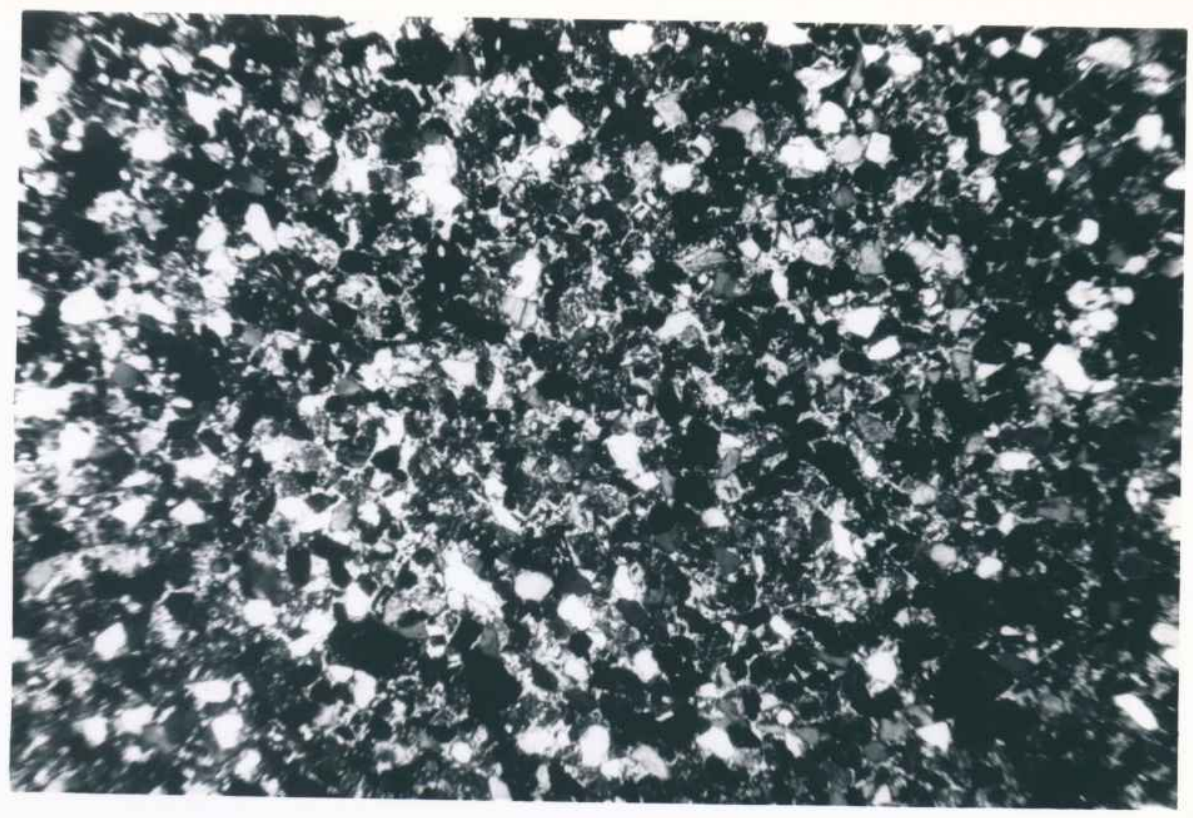

Figure 13. Photomicrograph of Roseburg Formation sandstone. White and gray - quartz and plagioclase, black - rock fragments. (polarized light) 
coarser-grained and showing many more common sedimentary structures such as channel fills and cross-bedding. The Lookingglass also contains pebbly sandstone and conglomerate whereas the Roseburg beds do not (Bounds and Gullixson, 1981).

In thin-section, the Lookingglass sandstone is mediumto-coarse-grained, poorly sorted, and clay cemented; the grains are angular to sub-rounded (Figure 14). Framework grains include quartz, igneous rock fragments, plagioclase, and notably, no metamorphic fragments. 


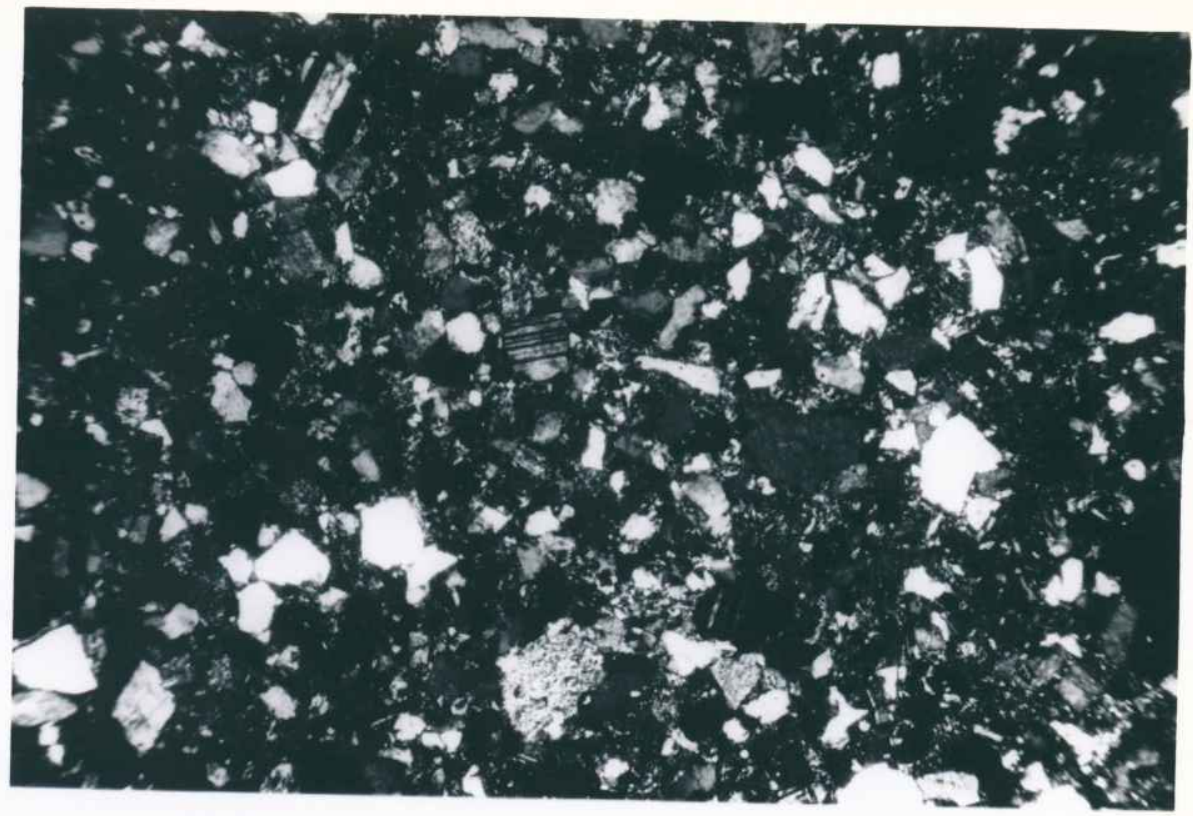

Figure 14. Photomicrograph of typical Lookingglass Formation sandstone. White and gray quartz and plagioclase, black - rock fragments. Field of view of $5 \mathrm{~mm}$. (polarized light) 


\section{DETRITAL MODAL ANALYSIS OF SANDSTONE}

A computer program, called FOLKSS (Jacob, 1975), (Appendix A), was modified to process point-count data from sandstone thin-sections. Input are raw point-counts of framework grains of sandstone. The program produces a modal analysis of each thin-section and names the sandstone type.

Dickenson (1970) and Dickenson and Suczek (1979), presented the basic methods for interpreting detrital modes for arkoses and graywackes. Table I shows the scheme used here for classifying sand grain types reported from pointcounts of Otter Point, Dothan, Franciscan, and Great Valley samples (Table II). Results from point-counts of ten thinsections from the Otter Point Formation sandstone in the study area (Plate I), and four thin-sections of the coeval Dothan sandstone, from a sample location on Mule Creek near the Rogue River, are compared to similar data from Dickenson and others (1982) on the Franciscan Complex and the Great Valley sequence. Table I concerns only the framework grains and not the interstitial and rare constituents. Table III defines grain parameters and grain populations which are then displayed on triangular diagrams. Following Dickenson (1982), quartz - feldspar lithic (QFL) and monocrystalline quartz - feldspar - total lithic (QmFLt) triangular plots were constructed to compare mean framework modes; and monocrystalline quartz - plagioclase - K-feldspar QmPK) and polycrystalline quartz - 


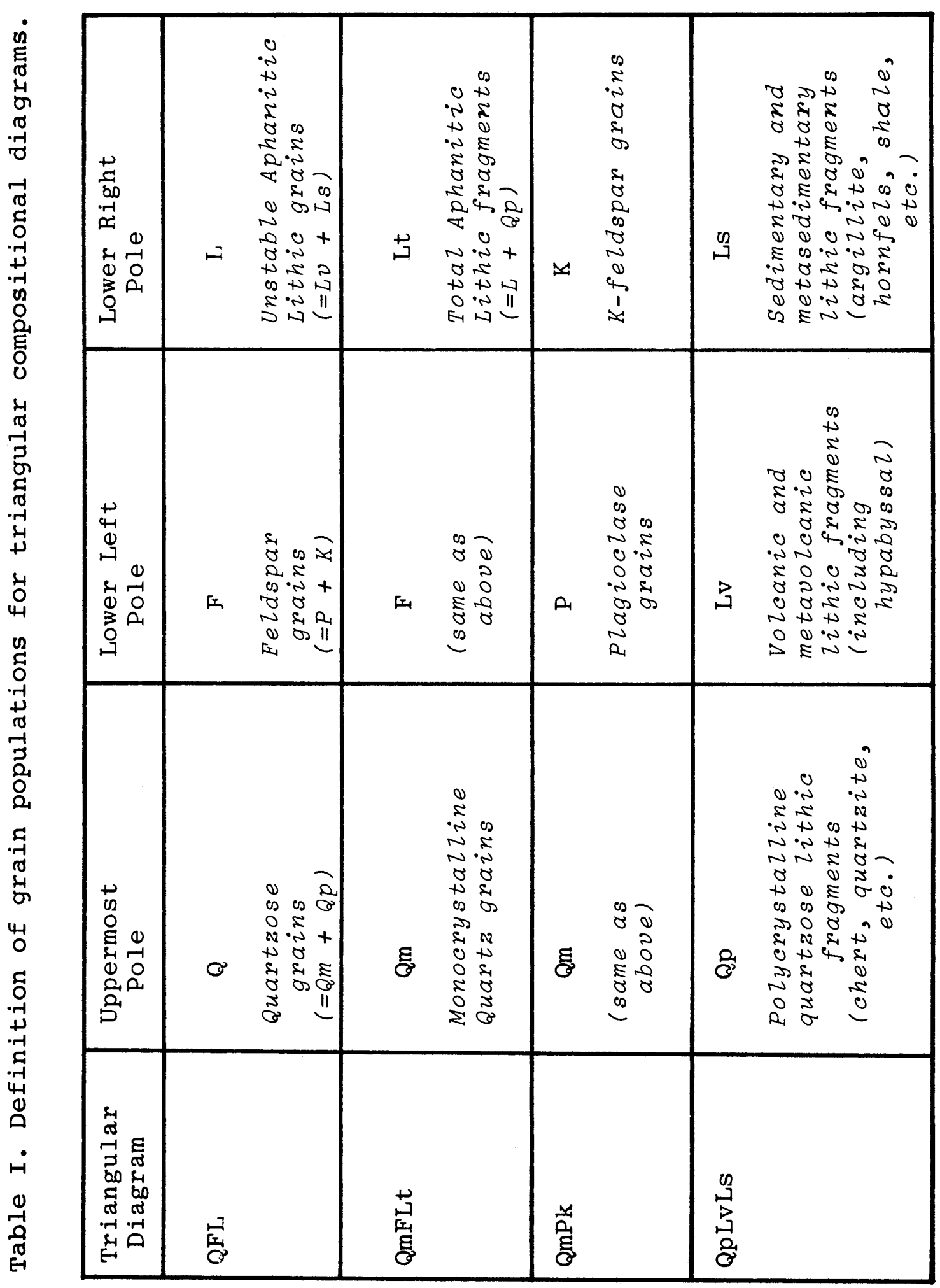


Table II. Sandstone point count data. Franciscan and Great Valley data from Dickenson and others (1982).

\begin{tabular}{|c|c|c|c|c|}
\hline \multirow[b]{2}{*}{ Sample No. } & \multicolumn{4}{|c|}{ Normalized Data for Triangular Diag. } \\
\hline & QFL & QmFLt & QpLVLS & $\mathrm{T} \mathrm{QmPK}$ \\
\hline $\begin{array}{l}\text { JDB }-80-10 \\
\text { JDB-80-12 } \\
\text { JDB-80-11 } \\
\text { CFG -JOP-01 } \\
\text { CFG -JOP-02 } \\
\text { CFG -JOP-03 } \\
\text { CFG -JOP-04 } \\
\text { CFG -JOP-05 } \\
\text { CFG -JOP-06 } \\
\text { CFG -JOP-07 }\end{array}$ & $\begin{array}{l}\text { OTTER POIN } \\
39-38-23 \\
59-39-2 \\
73-26-1 \\
61-0-39 \\
48-11-41 \\
58-20-22 \\
72-22-6 \\
57-30-13 \\
57-13-30 \\
36-14-50\end{array}$ & $\begin{array}{c}\text { FORMATIO } \\
18-38-43 \\
56-41-3 \\
61-26-13 \\
0-0-100 \\
5-11-84 \\
39-19-42 \\
53-22-25 \\
49-30-21 \\
21-12-67 \\
20-14-66\end{array}$ & $\begin{array}{l}\text { N } \\
46-2-52 \\
80-20-0 \\
92-8-0 \\
61-38-1 \\
52-45-3 \\
47-35-18 \\
73-19-8 \\
41-41-18 \\
54-34-12 \\
24-61-15\end{array}$ & $\begin{array}{r}32-68-0 \\
58-42-0 \\
70-30-0 \\
0-0-0 \\
31-69-0 \\
66-34-0 \\
71-29-0 \\
62-38-0 \\
63-37-0 \\
59-41-0\end{array}$ \\
\hline $\begin{array}{l}\text { B\&G -JDO -01 } \\
\text { B\&G -JDO -02 } \\
\text { B\&G -JDO - } 03 \\
\text { B\&G -JDO - } 04\end{array}$ & $\begin{array}{c}\text { DOTHAN FOR } \\
49-26-25 \\
58-18-24 \\
66-23-11 \\
69-23-8\end{array}$ & $\begin{array}{l}\text { MATION } \\
26-26-48 \\
40-18-42 \\
51-23-26 \\
53-23-24\end{array}$ & $\begin{array}{l}47-43-10 \\
44-39-17 \\
58-27-15 \\
67-25-8\end{array}$ & $\begin{array}{l}50-50-0 \\
70-30-0 \\
69-31-0 \\
70-30-0\end{array}$ \\
\hline $\begin{array}{l}F-1 \\
F-2 \\
F-3 \\
F-4 \\
F-5 \\
F-6 \\
F-7 \\
F-8 \\
G-1 \\
G-2 \\
G-3 \\
G-4\end{array}$ & $\begin{array}{c}\text { FRANCISCAN } \\
42-53-5 \\
35-42-23 \\
38-49-13 \\
35-54-11 \\
30-51-19 \\
33-54-13 \\
33-40-27 \\
42-48-10 \\
30-31-39 \\
29-40-31 \\
27-19-54 \\
33-33-34\end{array}$ & $\begin{array}{l}\text { ASSEMBLAG } \\
40-53-7 \\
28-42-30 \\
29-49-22 \\
35-54-11 \\
29-51-20 \\
29-54-17 \\
31-40-29 \\
37-48-15 \\
23-31-46 \\
24-40-36 \\
16-19-65 \\
28-33-39\end{array}$ & $\begin{array}{r}\text { E } 29-14-57 \\
23-44-33 \\
39-35-26 \\
3-22-75 \\
4-39-57 \\
24-41-35 \\
6-80-14 \\
31-26-43 \\
15-55-30 \\
15-59-29 \\
17-55-28 \\
11-52-37\end{array}$ & $\begin{array}{l}43-57-0 \\
40-60-0 \\
37-63-0 \\
40-60-0 \\
37-63-0 \\
36-65-0 \\
44-56-0 \\
44-54-1 \\
43-57-0 \\
38-61-1 \\
44-56-0 \\
45-54-1\end{array}$ \\
\hline $\begin{array}{l}D-1 \\
D-2 \\
D-3 \\
D-4 \\
D-5 \\
D-6 \\
D-7\end{array}$ & $\begin{array}{c}\text { GREAT VALI } \\
40-21-39 \\
37-21-42 \\
25-22-53 \\
22-27-51 \\
21-35-44 \\
17-15-68 \\
23-26-51\end{array}$ & $\begin{array}{c}\text { EY SEQUENC } \\
27-21-52 \\
29-21-50 \\
16-22-62 \\
17-27-56 \\
16-35-49 \\
14-15-71 \\
22-26-52\end{array}$ & $\begin{array}{c}25-22-53 \\
15-36-49 \\
15-51-34 \\
10=60-30 \\
10-60-30 \\
4-64-32 \\
2-90-8\end{array}$ & $\begin{array}{l}56-36-8 \\
59-35-6 \\
41-54-5 \\
40-50-10 \\
30-65-5 \\
50-44-6 \\
46-50-4\end{array}$ \\
\hline
\end{tabular}




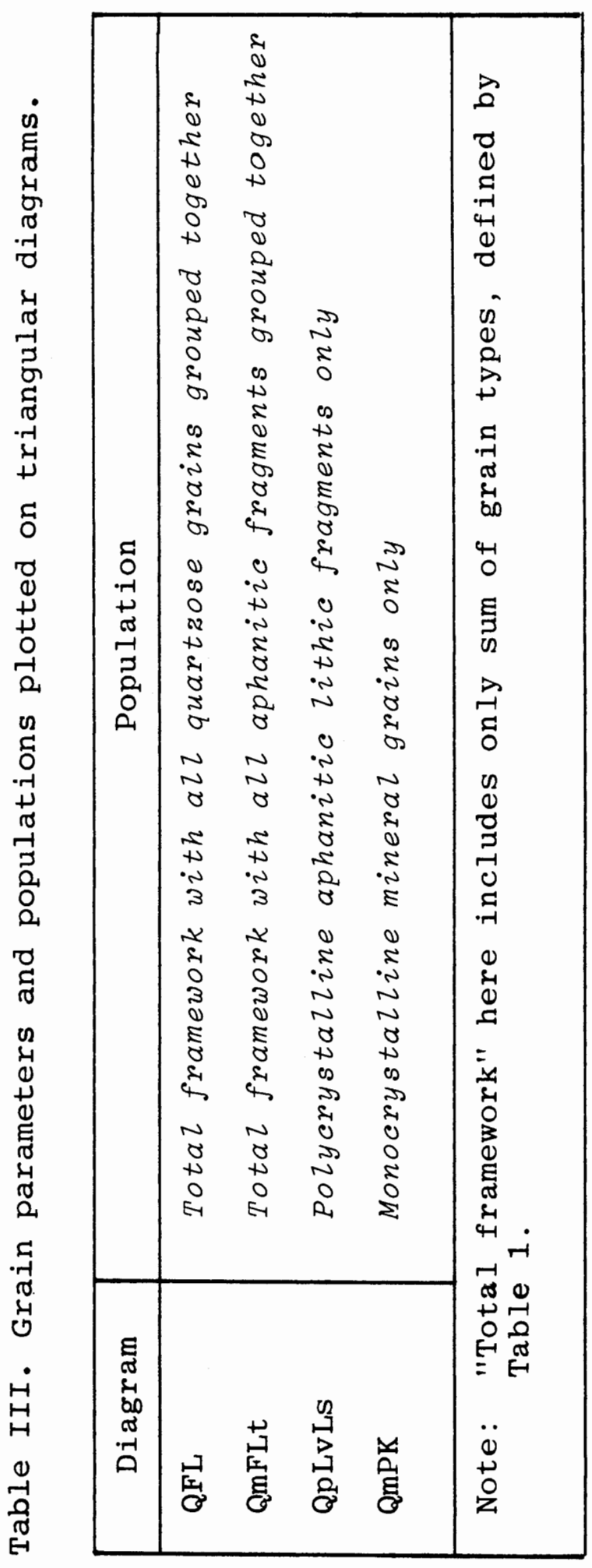


volcanic lithic - sedimentary lithic (QpLvLs) plots were constructed to show, respectively, partial modes of mineral grains and polycrystalline lithic fragments.

\section{QFL Diagram}

Figure 15 shows the distribution of the mean framework modes for selected samples or suites of sandstones from the Otter Point Formation, the Dothan Formation, the Franciscan Complex, and the Great Valley sequence (or Great Valley Group: Dickenson, 1981). The Franciscan and the Otter Point data plot into fields (estimated and drawn by hand) that have no overlap.

The Franciscan data points all fall below the $50 \%$ quartz line and the samples show a somewhat constant Q-F ratio. The Otter Point data plots into a field that tends to fall in a much more quartzose area. While the Franciscan has a fairly constant quartz/feldspar ratio with a changing lithic content, the Otter Point graywackes show a much more variable ratio of quartz to feldspar.

When the Dothan and Great Valley data are plotted on the same diagram, several relations can be noticed. The Great Valley data plots in a field that overlaps the more lithic-rich portion of the Franciscan field with a little greater variability in the quartz/feldspar ratio. The Dothan data plots in a field that lies wholly within the Otter Point field. 


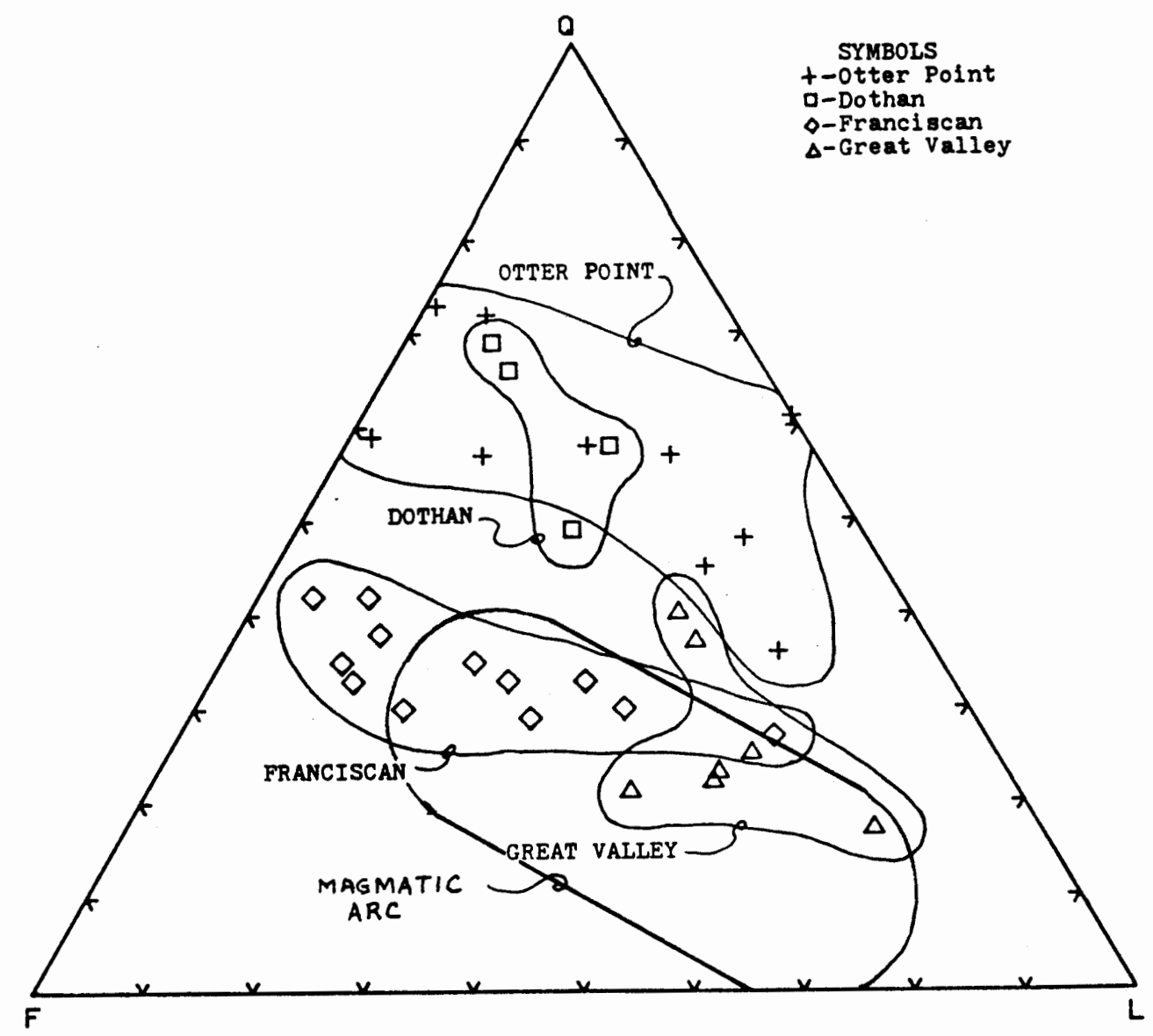

Figure 15. Quartz - Feldspar - Lithic triangular diagram. Franciscan and Great Valley data from Dickenson and others (1982). 
Both the Franciscan and the Great Valley fields overlap into the magmatic arc provenance field (Figure 15) defined by Dickenson and Suczek (1979) while the Otter Point and Dothan fields are located in a more quartzose region of the diagram than the magmatic arc provenance field.

\section{QmFLt Diagram}

The QmFLt diagram is used by Dickenson (1982) as a method of differentiating between trench and forearc basin deposits. This is possible because the chert component of the framework grains is removed from the quartz part of the diagram and is combined with the lithic components. The result is that the trench deposits plot a field that is more elongated toward the lithic apex of the QmFLt diagram than they do on the QFL diagram. The forearc basin sandstones show little or no change in shape or location of the plotted fields.

The Otter Point and Franciscan data fields overlap very little in the QmFLt diagram (Figure 16). Both show a fairly constant monocrystalline quartz/feldspar ratio with an extremely variable total lithic content. Again, as in the QFL diagram, the Otter Point data are more quartzose.

The Dothan samples plot totally within the Otter Point field. The shape of the Dothan data field indicates a little less variability of total lithic content and 


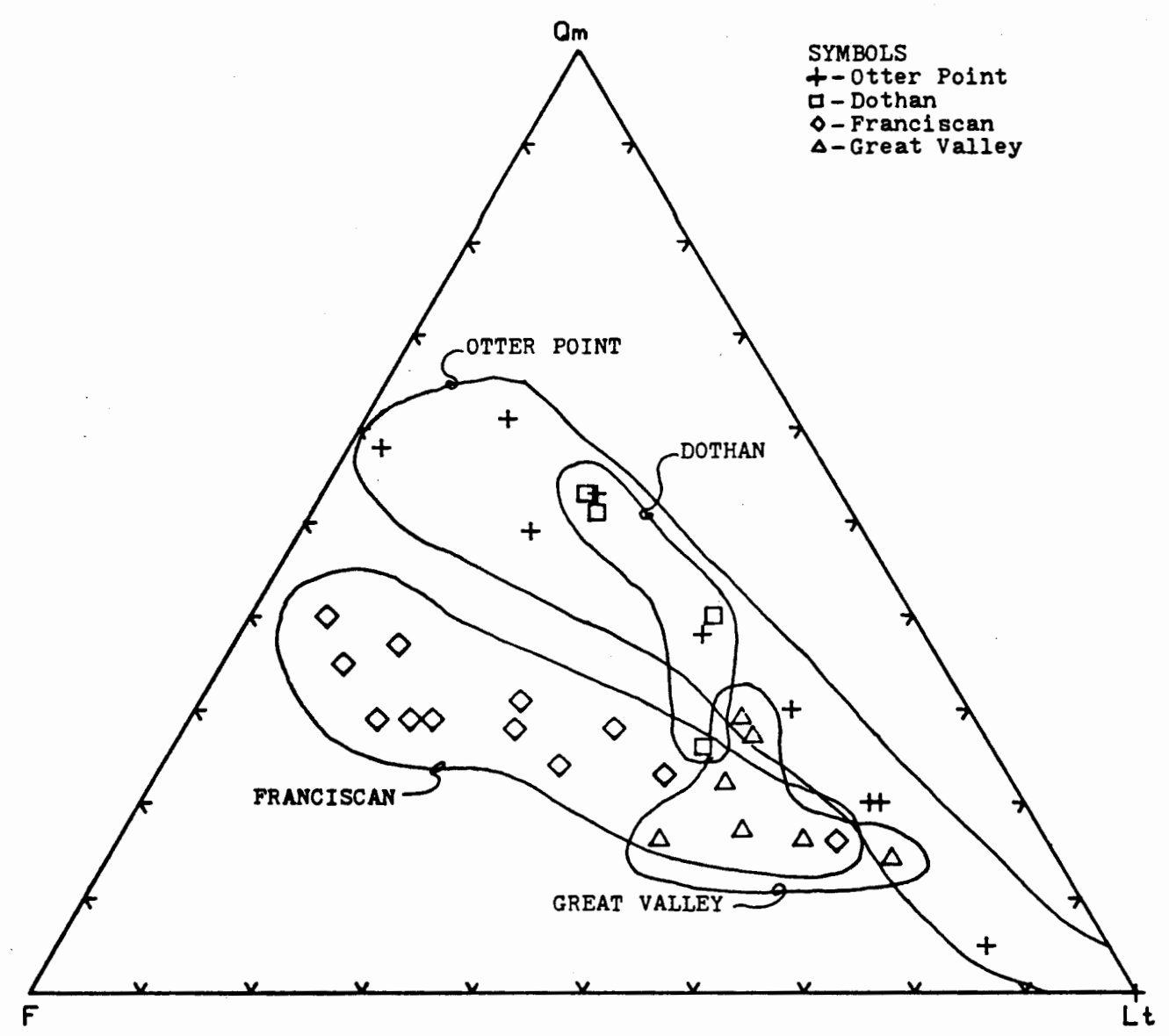

Figure 16. Monocrystalline quartz - Feldspar - Total lithic triangular diagram. Franciscan and Great V.alley data from Dickenson and others (1982). 
practically the same quartz/feldspar ratio as the Otter Point. The Great Valley data plot in an area that encloses the more 1ithic data from the Franciscan.

\section{QpLvLs Diagram}

In the QpLvLs diagram (Figure 17), the Otter Point and the Franciscan data fields are different from each other. The Franciscan data describe a field that indicates great variability in the ratio of volcanic lithic fragment to sedimentary lithic fragment content. Also, the data tend to fall below the 50\% Qp (polycrystalline quartz or chert) line. The Otter Point field shows a higher polycrystalline quartz content (overall) and generally, very little phyllosilicate-rich lithic fragment (LS) enrichment. Again as in the previous diagrams, the Dothan data falls within the Otter Point field and the Great Valley follows the Franciscan trend. Also, the Dothan and the Great Valley tend to form more compact data fields.

\section{QmPK Diagram}

The QmPK diagram (Figure 18) is used to show presence or absence of potash feldspar, therefore indicating provenance as plagioclase is predominant feldspar in the trench environment. The presence of potash feldspar and quartz enrichment indicates increased erosion of the arc.

The Otter Point and the Franciscan fields are very 


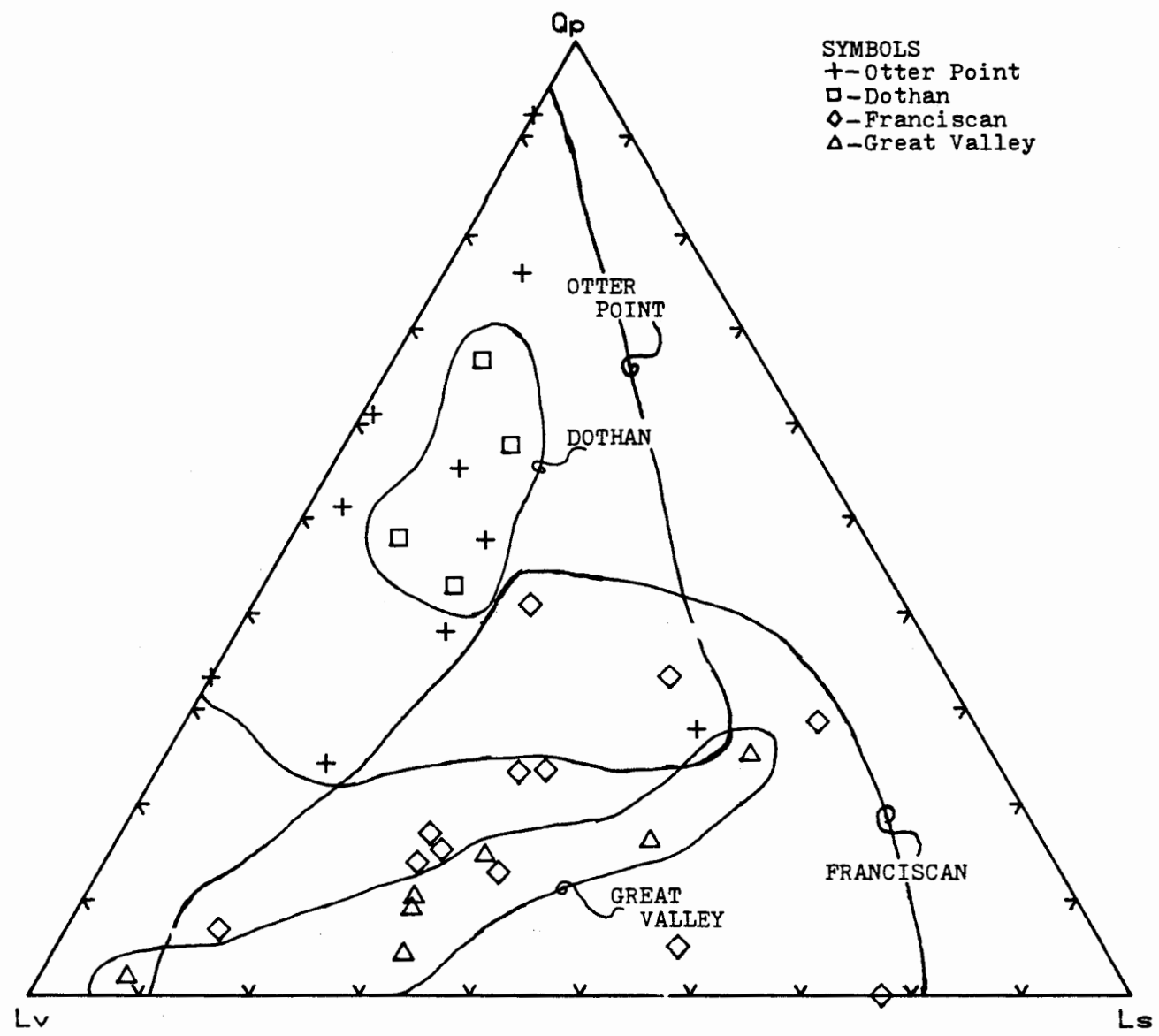

Figure 17. Polycrystalline quartz - Volcanic lithicSedimentary lithic triangular diagram. Franciscan and Great Valley data from Dickenson and others (1982). 


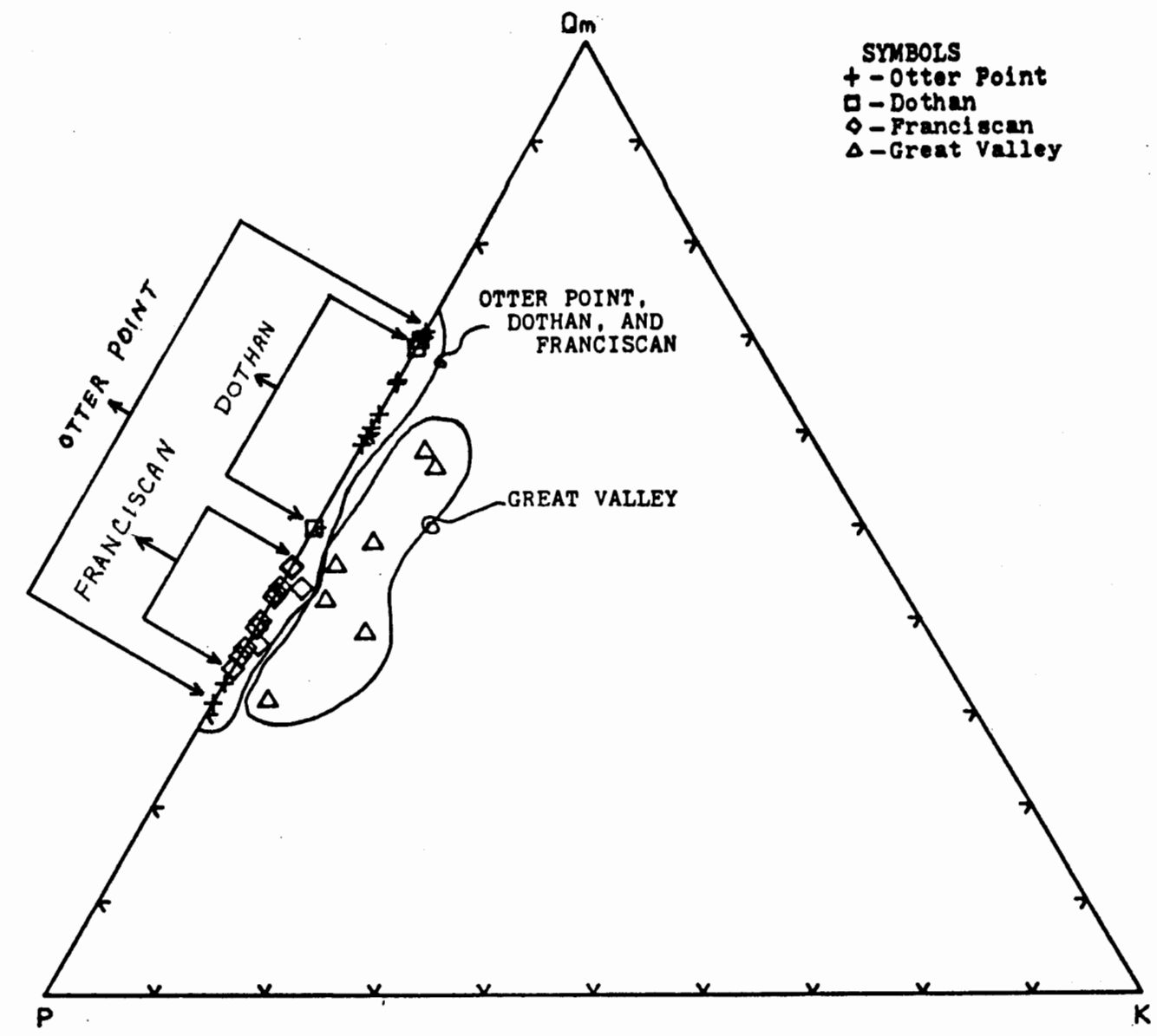

Figure 18. Ponocrystalline quartz - Plagioclase K-feldspar triangular diagram. Franciscan and Great Valley data from Dickenson and others (1982). 
much alike in this diagram (Figure 18). Both suites fall on the QmP line with very little or no K-feldspar present. The difference in the two fields are that the Otter Point samples are more quartz enriched than the F'ranciscan. This is shown by noting the location of the mean of the Qm-P proportions for each of the two assemblages. The mean of the Franciscan Qm-P proportions are $40.9 \%$ Qm and 59.1\% P whereas the mean of the Otter Point proportions are $64.2 \%$ $\mathrm{Qm}$ and $35.8 \% \mathrm{P}$.

The Dothan samples piot along the Qm-P line with no K-feldspar content at all. These samples show a little bit less variation in the $Q m / P$ ratio than the Otter Point. The Great Valley data plot near the Qm-P line but have a small ( $3 \%$ to $15 \%$ ) K-feldspar content. It also shows a wider range in $Q m / P$ ratio than the Franciscan does.

\section{DISCUSSION OF MODAL ANALYSIS}

Comparison of the Otter Point, Dothan, Franciscan, and the Great Valley point-data using detrital modal analysis appears to be meaningful. What this has indicated is that the Otter Point and the Dothan are closely related as the Franciscan and the Great Valley are closely related. It has also shown that the Otter Point/Dothan system is not directly related to the Franciscan/Great Valley system as far as provenance is concerned.

The most obvious difference ketween the two systems 
is the quartz enrichment of the Otter Point/Dothan system relative to the Franciscan/Great Valley system. This is most notable on the QFL and QmFLt diagrams.

Another noteworthy difference between the two systems is that the Otter Point system, relative to the Franciscan, shows a definite lack of phyllosilicate-rich lithic fragments (Ls) on the QpLvLs diagram (Figure 17). According to Dickenson and others (1982), the absence of sedimentary or metasedimentary lithic fragments could be attributed to the lack of reworking of the sediments near the trench slope. These workers proposed that with much reworking of sediments on the trench slope, the volcanic lithics are broken down and the argillite and chert fragments are recycled.

In the QFL diagram (Figure 15), enrichment in quartzose material in the Otter Point/Dothan system relative to the Franciscan/Great Valley system is immediately apparent. This, according to Dickenson and others (1982), could possibly be the result of deeper dissection of the magmatic arc which furnished sediments to the fore-are system. With increased erosion of a magmatic arc, increased content of quartz should be noted in the trench slope and fore-arc basin sediments (Figure 19).

The triangular diagrams (Figures 15, 16, 17, 18) show consistant overlap between detrital compositions of the Otter Point and Dothan sandstones, and between the Francis- 


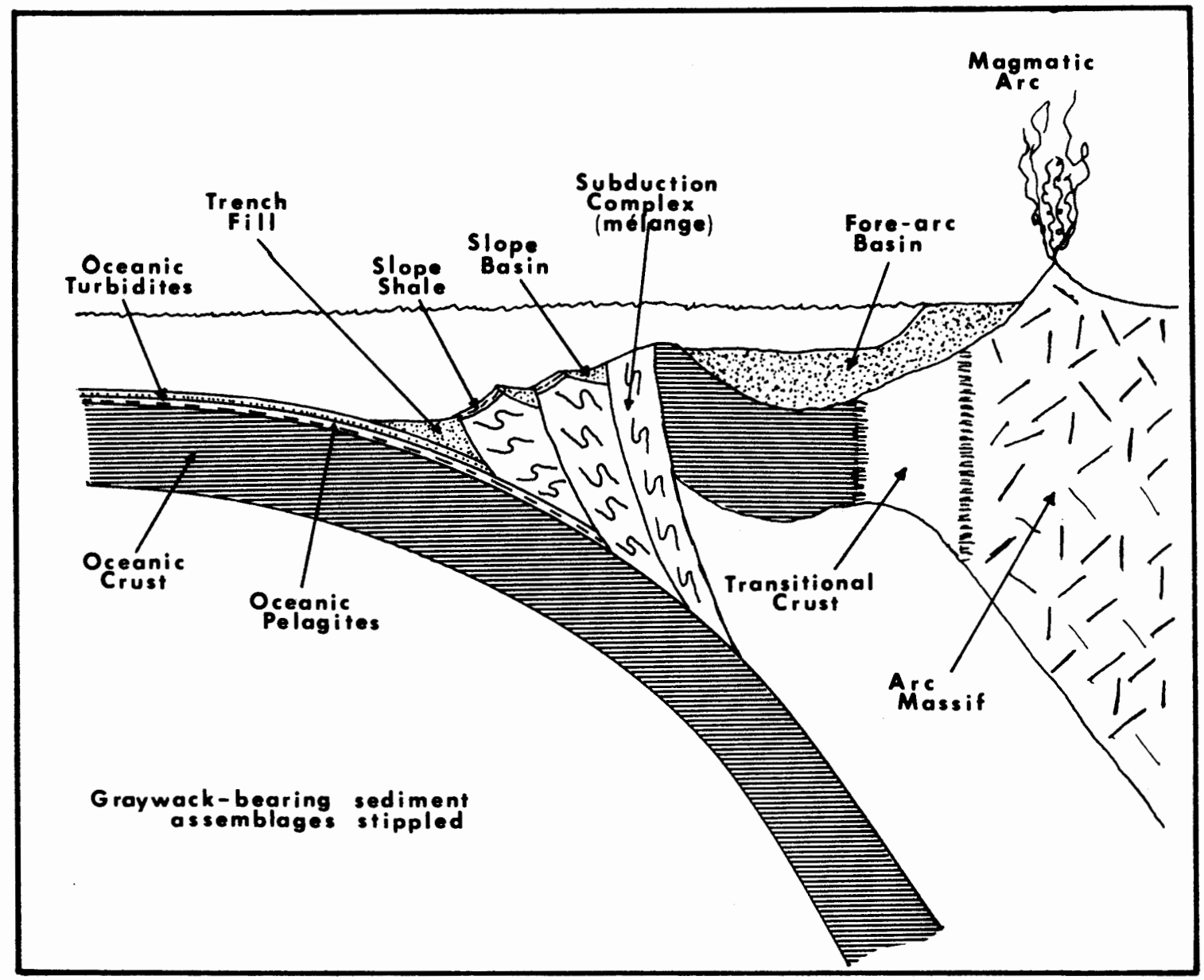

Figure 19. Schematic diagram of a typical arc-trench system (no scale) showing varied sandstone depcsitional sites. After Dickenson and Seely (1979). 
can and Great Valley sandstones. Conversely, the diagrams show a definite lack of overlap between the Otter Point/ Dothan system and the Franciscan/Great Valley system. However, the differences between the two systems is primarily in the difference in the higher proportion of monocrystalline quartz $(\mathrm{Qm})$ in the Otter Point/Dothan system. Both systems still best fit the forearc-trench environment. The differential might be attributed to deeper erosion of the magmatic arc in the Otter Point/Dothan system. Of course, the modal data can only show that the two parts of each pair had a similar provenance, but cannot prove that the two pairs were derived from the same magmatic arc.

The data suggest that the Franciscan/s reat Valley set might have been derived from a completely different arc provenance than the Otter Point/Dothan set. This could as well be attributed to widely separated parts of the same arc system, with differing degrees of dissection and erosion, furnishing the sediments for the two cairs of rock suites (Figure 20). 


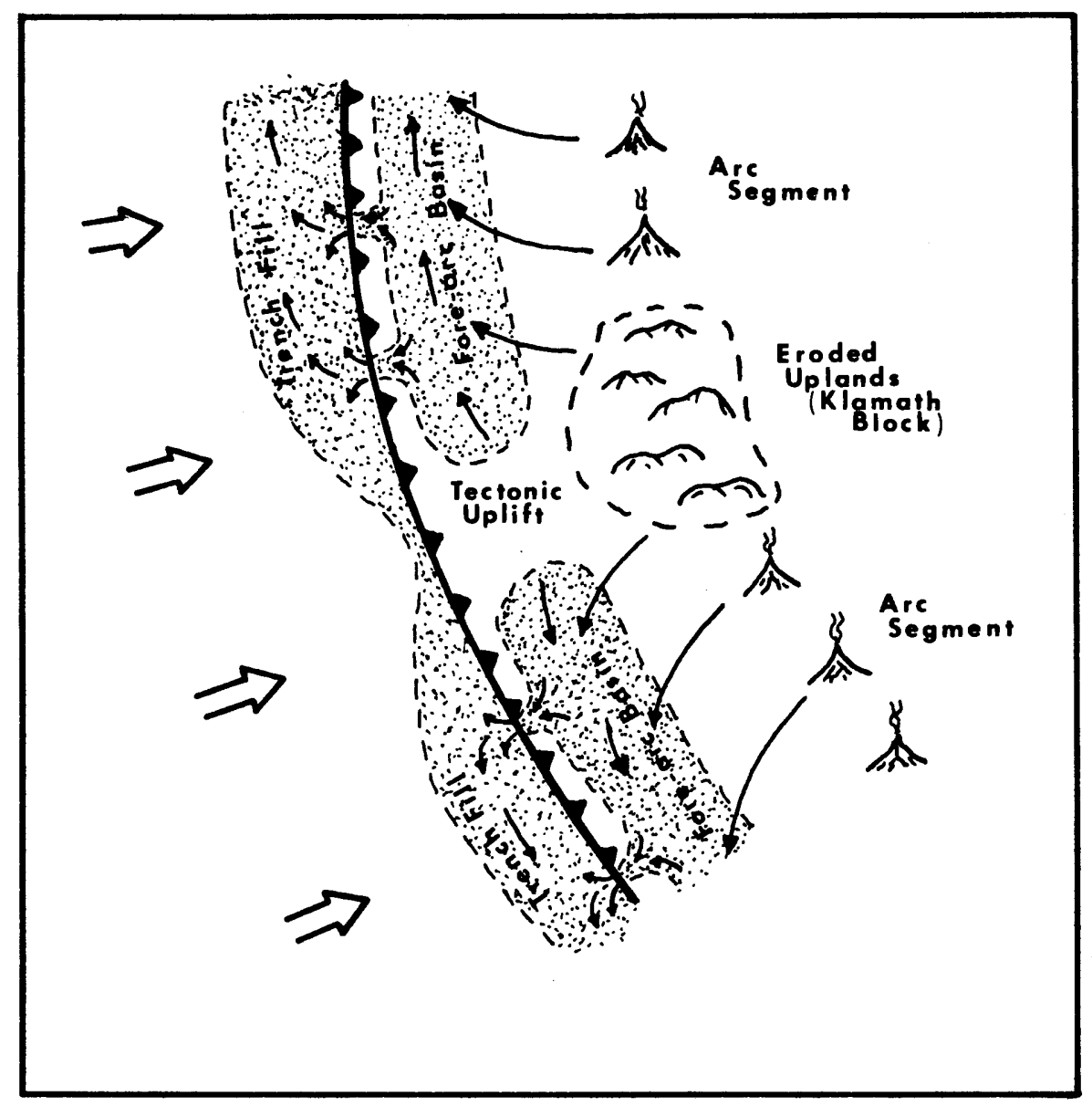

Figure 20. Cartoon suggesting possible relations of a subduction zone with a highiy eroded highland separating two less highly eroded segments of the ragmatic arc. The sovthern trench fill and fore-arc basin pair could possibly be the Franciscan and the Great Valley while the northern pair could possibly be the Otter Point and Dothan. 


\section{STRUCTURAL GEOLOGY}

North-south trending faults characterize the coastal section of the Klamath Mountains (Dott, 1971), and the east-west trending Canyonville fault forms the northern boundary of the interior Klamath Mountains east of the study area (Benson and Perttu, 1980). Two structural trends are apparent in the Floras Creek area. The north-south trending faults in the area belong to the coastal system; the east-west trending structures may or may not be related to the Canyonville trend.

NORTH-SOUTH TRENDING STRUCTURE

The dominance of the north-south structural trend is readily discerned, both from the map of the study area (Plate I) and from east-west cross-section $A-A^{\prime}$ (Plate II). Most notable are the two very large shear zones which trend north-northeast in the western third of the mapped area. The predominant rock within these zones is serpentinite (Jsp) containing highly altered pyroxenite nodules. The serpentinite is pervasively sheared throughout the zones and exhibits slickensides aligned parallel or sub-parallel to the shear zones with very low plunges. Basalt, blueschist, and chert exotic blocks are found within the largest north-trending serpentinite zone.

The eastern and western boundaries of the Colebrooke Schist (Plate I) appear to be normal faults. These north- 
to northeast-trending normal faults separate the Colebrooke from the Otter Point, and continue northward, cutting the Roseburg Formation.

EAST-WEST TRENDING STRUCTURE

In the northeastern part of the area, a generally east-west block of Otter Point is flanked on the north and south by Roseburg (Plate I). Although the contacts are mostly faults, the overall pattern suggests an east-west trending anticline. Two large east-west trending serpentinite bodies which mark shear zones are evident in the northcentral part of the area (Plate I).

Northeast-southwest cross-section B-B' (Plate II) shows the basic order of the formations within the study area. The Roseburg Formation appears to be in depositional contact with the Otter Point Formation in Sections 2, 3, 34 , and 35 (Plate I).

To the southwest end of cross-section B-B', the Colebrooke Schist (JC) is shown to overlie the Roseburg in a thrust relationship, but alternatively, this contact could be the base of a large earthflow-landslide as discussed on page 9. In the southwest part of the mapped area (Sec. 13)(Plate I), the Colebrooke Schist is exposed in thrust contact with the underlying Otter Point. This agrees with the relationship of the Colebrooke as klippen on the Otter Point as recognized by Coleman (1972). There 
is no indication in the region of continuation of thrusting into the Eocene; therefore the landslide interpretation is preferred for the Colebrooke/Roseburg contact relationship.

\section{INTERNAL STRUCTURE}

In the north-central part of the area near Millard School (Plate I), there is a small (0.5 sq. $\mathrm{km}$ ) body of Tertiary Lookingglass Formation. It appears to be in depositional contact with the Otter Point and is truncated at the western tip by the largest of the north-south shear zones. There are numerous small normal faults, all down to the south-west.

As previously mentioned, the Otter Point Formation abounds with exotic "knockers" of basalt, blueschist, and chert. Some "knockers" (predominately basalt) are contained within both the north-south and the east-west shear zones. A dispersion pattern of "knockers" could not be discerned other than the population density is higher in the western half of the mapped area.

\section{DISCUSSION}

The occurrence of the Colebrooke as a klippe on the Otter Point may be apparent to the south (Coleman, 1972), but it is not so obvious in the Floras Creek area. The thrust contact of Colebrooke on Otter Point is mapped only in the southwestern and southern parts of the area (Plate 
I); elsewhere the Colebrooke is in high-angle fault contact with the Otter Point. Along its northern boundary, the Colebrooke appears to overlie Roseburg along an east-west trending thrust, but as noted above, this contact is interpreted to be a large landslide (there is no evidence for the alternative that thrust emplacement of the Colebrooke continued into Eocene Roseburg time).

North-south trending faults generally cut off east trending structures. This suggests that the north-south trending structures are more important or younger, or both. The two are probably correct. Similar large fault zones have not been mapped in the Tertiary to the north (Wells and Peck, 1961), so the major deformation in the area was presumably late Mesozoic. On the other hand, lesser movements presumably continued into the Tertiary along preexisting lines as indicated by fault contacts of Eocene units (Gullixson, 1981). 
CONCLUSIONS

WHAT IS THE OTTER POINT FORMATION?

Prior to the advent of the plate-tectonic theories, the origin of the Otter Point Formation and the Franciscan Complex were enigmatic. Now, both assemblages are general1y regarded as subduction complexes, deposited on and deformed within and beneath the inner slope of a late Mesozoic trench along the western margin of North America (Dott, 1971).

Dickenson (1982) and Dickenson and others (1982) thoroughly investigated the compositions of sandstones of subduction complexes and in particular the provenance of Franciscan graywackes and the Great Valley sandstones of California. In these papers, they noted that the arctrench systems of the circum-Pacific orogenic belts contain abundant sandstones within fore-arc terranes that include subduction complexes (Figure 19). Turbidites incorporated within subduction complexes include not only axially transported trench fill, but also abyssal plain sediments deposited on the sea floor beyond the trench, indicated by the presence of bedded radiolarian chert, and slope-basin deposits perched on the accretionary trench slope.

The Otter Point Formation is composed of highly sheared "knockers" of sandstone, metavolcanic greenstone, 
radiolarian chert, and glaucophane schist, scattered within a matrix of sheared mudstone, argillite, and clay.

These "knockers" do not form any obvious pattern in the way that they are scattered within the matrix. Cloos (1982) accounted for this lack of organization in his explanation of the flow melanges in the Franciscan subduction complex. He concluded that many of these blocks had been buried at depth beneath the hanging wall of the overriding plate (Figure 21). He also suggested that melanges (such as the Franciscan) which contain exotic blocks in a pelitic matrix, are zones in which a forced convection or "reverse" flow occurred in sediment accreted into the wedge. The reverse or forced flow "plucked" blocks of different lithologies and metamorphic grades depending on the depth at which these blocks were removed from the hanging wall. According to Cloos' (1982) model, the pelitic muds and shales are not metamorphosed because of the lack of Ca-silicates and carbonates. This may be true, but there is also the probability that some of the rocks, including some of the basalts, were not carried as deeply within the subduction system (Figure 2l). In particular, the ideas of the basalts being carried to a variety of depths could account for the differing degrees of metamorphism of the basalts in the Otter Point Formation.

The Otter Point Formation is many ways resembles the Franciscan Complex. It consists of similar rock type 


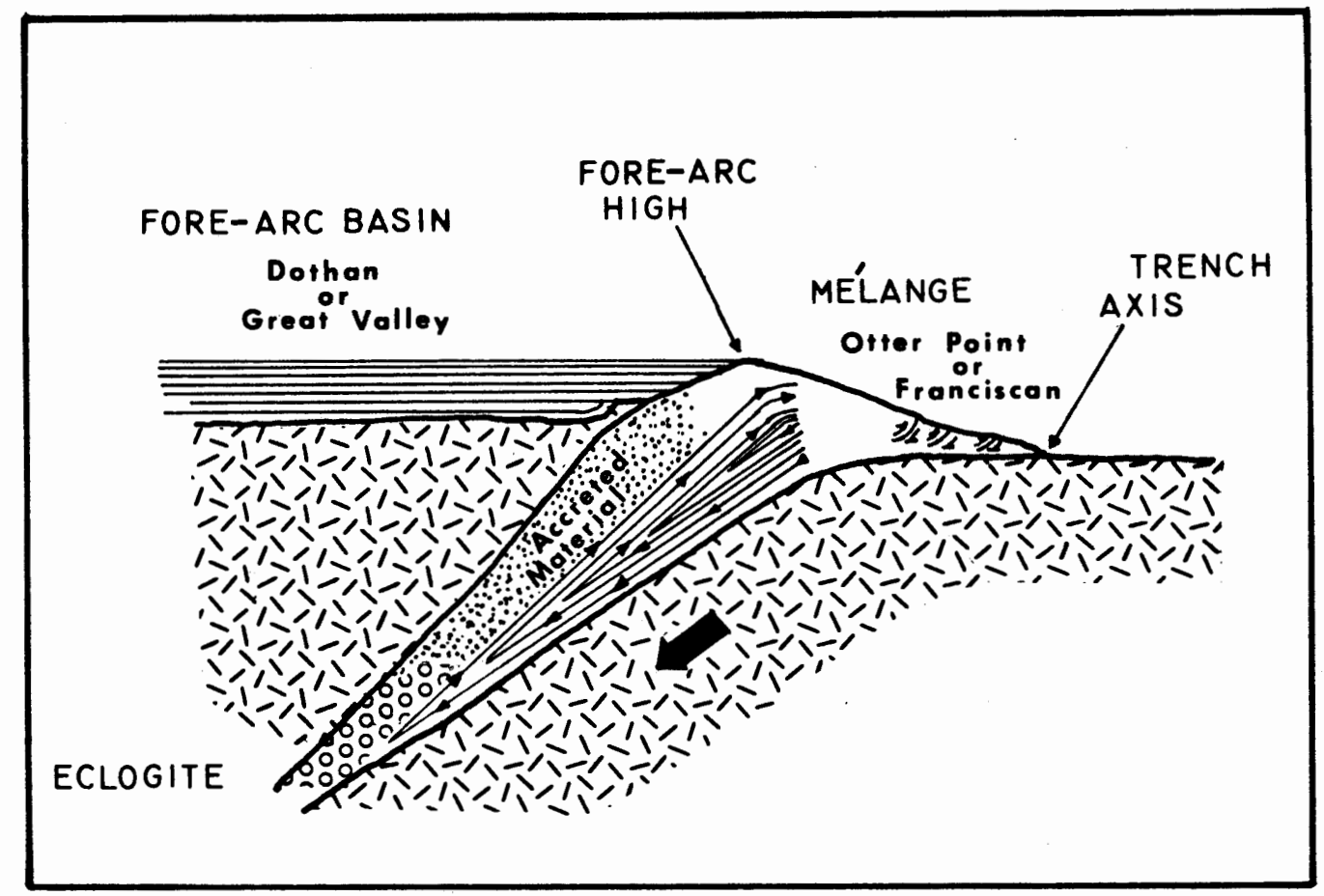

Figure 21. Schematic cross section illustrating the circulation pattern of otter Point or Franciscan flow melange during late Mesozoic convergence. (After Clocs, 1982) 
occurring in a similar fashion, that is, a native blockexotic block assemblage within a highly sheared mud and shale matrix. Both Otter Point and Franciscan typically show chaotic internal structure.

When the sedimentology of the Otter Point, Dothan, Franciscan, and Great Valley are compared, many similarities are apparent, but differences are evident as well. All four assemblages fall into the area of feldspathic to lithofeldspathic graywackes. Triangular diagrams of sandstone constituents show the similarity of the Otter Point and the Dothan and also the similarity of the Franciscan and the Great Valley. However, the provenances of the Otter Point and the Franciscan graywackes are somewhat different. Otter Point source terrane furnished a more quartz-rich sediment than the source terrane of the Franciscan.

Workers in California (Imlay and others, 1959) have mapped the Franciscan Complex continuing northward into Oregon. On the other hand, workers in Oregon have mapped the Otter Point only as far south as its contact with the Macklyn Member of the Dothan north of the California border.

The relationship of the Otter Point to the Dothan Formation remains a problem. To date, there has not been enough comparative work done to answer a basic question: Are the Otter Point and the Dothan the same formation, or do they have a relationship with each other similar to 
that of the Franciscan and the Great Valley?

Dickenson (1982) attributed the north-south variations of detrital compositions in the Franciscan and the Great Valley to differing degrees of erosion and dissection of the magmatic arc source. Deep erosion of the source terrane would supply sediment enriched in quartz, K-spar, and metamorphic rock particles from the plutonic core and metamorphic halo. In contrast, sediments derived from a little eroded portion of the magmatic arc would consist mainly of plagioclase and volcanic lithic fragments with quartz and $\mathrm{K}$-spar .

The total lack of $\mathrm{K}$-feldspar in Otter Point sandstones could possibly be due to the complete albitization of that mineral. This process has been noted in the Franciscan Complex by Dickenson and others (1982), Moore and Liou (1979), and Cowan (1974), and therefore could very well be true for the Otter Point Formation.

The Otter Point sediments could have been derived from a more dissected and eroded magmatic arc complex and therefore would have received a more quartz-rich sediment, and with the albitization of the K-feldspar, only quartz, plagioclase, and the lithics would remain.

From descriptions of Well and Walker (1953), Dott (1971), and Black (1979), the Dothan Formation does not appear to be a melange. It does not contain native and exotj.c blocks in a sheared matrix. The sandstone is 
relatively unbroken tectonically and appears to be fairly consistent lithologically. Also, the sandstone (graywacke) seems to be much more massive and less conglomeratic than the Otter Point (Dott, 1971).

The lithologic similarities of the Otter Point Formation to the Macklyn Member of the Dothan Formation could possibly suggest that these are the same rocks. On the other hand the Macklyn has the same north-northeast strike trend as does the rest of the Dothan Formation while the Otter Point tends to have a random pattern of strike directions due to the broken and chaotic nature of a melange. 
Baldwin, E.M., 1974, Eocene stratigraphy of southwestern Oregon: Oregon Dept. Geol. and Mineral Indus. Bull. $83,40 \mathrm{p}$.

Benson, G.T., and Perttu, R.K., 1980, The Canyonville Fault-Northern Boundary of the Klamath Mountains: Oregon Academy of Science Abs.: vol. XVI, $18 \mathrm{p}$.

Black, G.L., 1979, Structural geology of the southeast quarter of the Dutchman Butte Quadrangle, Oregon: Portland State Univ. master's thesis: 108 p., unpub.

Bounds, J.D., and Gullixson, C.F., 1981, Geology of a portion of the Langlois Quadrangle, Coos and Curry Counties, Oregon: Oregon Academy of Science Abs., vol. XVII, $21 \mathrm{p}$.

Brownfield, M.E., 1969, Geology of the Floras Creek drainage, Langlois Quadrangle, Oregon: Univ. Oregon master's thesis, $104 \mathrm{p}$., unpub.

Cloos, M., 1982, Flow Melanges: Numerical modeling and geologic constraints of their origin in the Franciscan subduction complex, California: Geol. Soc. Am. Bull., v. 93, no. 4, p. 330-345.

Coleman, R.G., 1972, The Colebrooke Schist of Southwestern Oregon and its Relation to the Tectonic Evolution of the region: U.S. Geol. Survey Bull. 1339, $61 \mathrm{p}$.

Coleman, R.G., and Lanphere, M.A., 1971, Distribution and age of high-grade blueschists, associated eclogites and amphibolites from Oregon and California: Geol. Soc. of Am. Bull., v. 82, p. 2397-2412.

Connelly, W., 1978, Uyak Complex, Kodiak Islands, Alaska: a Cretaceous subduction complex: Geol. Soc. of Am. Bull., v. 89, p. 755-769.

Cowan, D.S., 1974, Deformation and metamorphism of the Franciscan subduction complex northwest to Pacheco Pass, California: Geol. Soc. of Am. Bull., v. 85, p. 1623-1634.

Dickenson, W.R., 1970, Interpreting detrital modes of graywacke and arkose: Jour. of Sedimentary Petrology, v. 40, p. 695-707. 
Dickenson, W.R., 1982, Compositions of sandstones in circum-Pacific subduction complexes and fore-arc basins: Am. Assoc. of Petroleum Geologists Bull., v. 66, no. 2, p. 121-137.

Dickenson, W.R., and Seely, D.R., 1979, Stratigraphy and structure of fore-arc regions: Am. Assoc. Petroleum Geologists Bull., v. 63, p. 2-31.

Dickenson, W.R., and Suczek, C.A., 1979, Plate tectonics and sandstone compositions: Am. Assoc. Petroleum Geologists Bull., v. 63, p. 2164-2182.

Dickenson, W.R., Ingersol1, R.V., Cowan, D.S., Heldmold, K.P., and Suczek, C.A., 1982, Provenance of Franciscan graywackes in coastal California: Geol. Soc. Am. Bul1., v. 93, no. 2, p. 95-107.

Diller, J.S., 1903, Port Orford Folio: U.S. Geol. Survey Geol. Atlas of the U.S., Folio 89.

Diller, J.S., 1907, The Mesozoic sediments of southwestern Oregon: Am. Jour. Sci., 4th ser., v. 23, p. 401-421.

Dott, R.H., Jr., 1962, Geology of the Cape Blanco area: The Ore Bin, Oregon Dept. Mineral Industries, v. 24, no. 8, p. 121-133.

Dott, R.H., Jr., 1971, Geology of the southwestern Oregon coast west of the 124th meridian: Oregon Dept. Geol. and Mineral Industries Bull. 69, $63 \mathrm{p}$.

Gullixson, C.F., 1981, The structure, geologic evolution, and regional significance of the Bethal Creek-North Fork area, Coos and Curry Counties, Oregon: Portland State Univ. master's thesis, $86 \mathrm{p}$., unpub.

Hsu, K.J., 1968, Principles of melanges and their bearing on the Franciscan-Knoxville paradox: Geol. Soc. of Am. Bull., v. 79, p. 1063-1074.

---, 1971, Franciscan melanges as a model for eugeosynclinal sedimentation and underthrusting tectonics: Jour. of Geophysical Research, v. 76, p. 1162-1170.

Imlay, R.W., Dole, H.M., Wells, F.G., and Peck, D., 1959, Relations of certain Jurassic and Lower Cretaceous formations in southwestern Oregon: Am. Assoc. Petroleum Geologists Bull., v. 43, no. 12, p. 27702785 . 
Jacob, A.F., 1975, FOLKSS: a FORTRAN program for petrographic classification of sandstones: Computer \& Geosciences, v. 1, p. 97-104.

Jones, D.L., 1969, Buchia zonation in the Myrtle Group, southwestern Oregon: Abstract, Geol. Soc. Am., Cordilleran Sec. Ann. Mts., Eugene, Oregon, Abstracts with Programs for 1969, part 3, p. 31-32.

Koch, J.G., 1966, Late Mesozoic stratigraphy and tectonic history, Port Orford-Gold Beach area, southwestern Oregon: Am. Assoc. of Petroleum Geologists Bull., v. 50, no. 1 , p. 25-71.

Lent, R.L., 1969, Geology of the southern half of the Langlois Quadrangle, Oregon: Univ. Oregon doctoral dissert., 189 p., unpub.

Ramp, L., 1964, Geologic adventures on the lower Illinois River, southwestern Oregon: The Ore Bin, v. 26, no. 6, p. 97-108.

Scholl, D.W., von Heune, R., Vallier, T.L., and Howell, D.G., 1980, Sedimentary masses and concepts about tectonic processes at underthrust ocean margins: Geology, v. 8, p. 564-568.

Wells, F.G., and Peck, D.L., 1961, Geologic map of Oregon west of the 121st meridian: U.S. Geol. Survey Misc. Inv. Map I-325, in coop. with Oregon Dept. of Geol. and Mineral Industries.

Wells, F.G., and Walker, G.W., 1953, Geologic map of the Galice Quadrangle, Oregon: U.S. Geol. Survey map GQ-25.

Widmier, J.M., 1962, Mesozoic stratigraphy of the westcentral Klamath Province: a study of eugeosynclinal sedimentation: Univ. Wisc. Ph.D. thesis, unpub. 
APPENDIX A

FOLKSS Computer Program Used for Detrital Modal Analysis. 
$30 \mathrm{C}$

$40 \mathrm{C}$

$50 \mathrm{C}$

$60 \mathrm{C}$

$70 \mathrm{C}$

$80 \mathrm{C}$

$90 \mathrm{C}$

1000

$110 \mathrm{C}$

1200

$130 \mathrm{C}$

$140 \mathrm{C}$

$150 \mathrm{C}$

$160 \mathrm{C}$

$170 \mathrm{C}$

$180 \mathrm{C}$

$190 \mathrm{C}$

$200 \mathrm{C}$

$201 \mathrm{C}$

$210 \mathrm{C}$

$220 \mathrm{C}$

$230 \mathrm{C}$

$231 \mathrm{C}$

$240 \mathrm{C}$

250

260

270

280

290

300

310

320

330

340

350

360

370

380

390

400

$410 \mathrm{C}$

$420 \mathrm{C}$

$430 \mathrm{C}$

440

450

$460 \mathrm{C}$

$470 \mathrm{C}$

$480 \mathrm{C}$

490

500

$510 \mathrm{C}$

$520 \mathrm{C}$

530C

540

550

$560 \mathrm{C}$

$570 \mathrm{C}$

seoc

$$
\text { F } 0 \text { L } K S S
$$

THIS FROGRAM CLASSIFIES AND NAMES SANDSTONES ACCOKLING TO THE CLASSIFICATION OF FOLK AND OTHERS (1970, NEW ZEALANI JOURNAL GEOLOGY AND GE(SPHYSICS, $U .13, F, 937-968)$. THE FFOGFAM CALCULATES THE PERCENT MINERAL COMPOSITION OF THE TOTAL ROCK AND THE FRAMEWORK. IT ALSO CALCULATES THE F'ER'CENT QTZ-TYFE COMPOSITION OF THE QUARTZ FRACTION, UNLESS QTZ TYPES ARE EXCLUDED FROM THE INFUT. IF ONLY THE MAIN COMFONENTS $(Q, F, R, C, M, F, O)$ ARE USEI AS INFUT, A NAME FOR TME MAIN TRIANGLE ONLY WILL BE PRINTED. MOST ZERO OUTFUT WILL NOT BE FRINTEII. FOR ALL SANIISTONES THE PROGRAM RECALCULATES QUARTZ (EXCEFT CHERT) FLUS FELUSFAR FLUS ROCK FRAGMENTS TO 100 PERCENT. FOR SANIISTONES CONTAINING ABUNDANT ROCK FRAGMENTS THE PROGRAM RECALCULATES THE TOTAL ROCK-FRAQMENT FART OF THE FRAMEWORK TO 100 FERCENT ANL, WHERE APPROPRIATE, IT RECALCULATES THE SEUIMENTARY-ROCK-FFAGMENT PART OF THE FRAMEWORK TO 100 PERCENT. IT THEN FLOTS THE APPROFRIATE TRIANGLES.

THIS PROGRAM MODIFIED FOR THE HARRIS 220 GY JON D. BOUNDS, JANUARY 31,1979 AND FOR THE HONEYWELL 66/20, SEPTEMBER, 1980.

INTEGER $Y, Z$

REAL KF, MR,M, MFO

DIMENSION RECQ(200), RECF (200), RECR (200), PRSR(200), FFIIR(200)

8 ,PRAR (200), ,FRCR (200), PRSHR (200), PRCHR (200), SFLNO(15)

NREAD $=22$

NHRIT $=23$

$N=0$

$I=1$

READ (NREAD, 5010) N

DO $9999 Y=1, N$

READ (NREAD, 5000) :SPLNO(Z), $Z=1,15), Q, S T Q, U Q, M F Q, O F Q, F, K F, F F, R, C F$ READ ( 22, 5005) SHR , CHR, UR, PR, MR , C, CAC, SIC, FEC, OC, M, F, O $T C O M P=Q+F+R+C+M+P+O$

WRI TE (NWRIT, 9990)

WRITE (NWRIT , 6000) (SPLNO $(Z), Z=1,15$ ), TCOMF, Q, STQ, UQ, MFQ, OFQ, F, KF, FF,

\& $R, C R, S H R, C H R, U R, P R, M R, C, C A C, S I C, F E C, O C, M, P, O$

******************************************1

DOES $Q$ = SUM OF QTZ TYPES (TQ)?

$T Q=S T Q+U Q+M P Q+O P Q$

IF (Q-TQ) $20,11,20$

******************************************1

DOES $F=$ SUM OF FELDSPAR TYPES (TF)?

11 TF =KF +FF

IF (F-TF) $20,12,20$

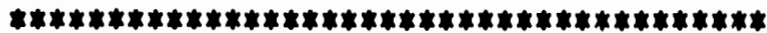

DOES $R$ = SUM OF ROCK-FRAG TYPES (TR)?

$12 T R=C R+S H R+C H R+U R+P R+M R$

IF $(R-T R) \quad 20,13,20$

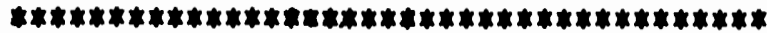

DOES $C$ - SUM OF CEMENT TYPES (TC)? 


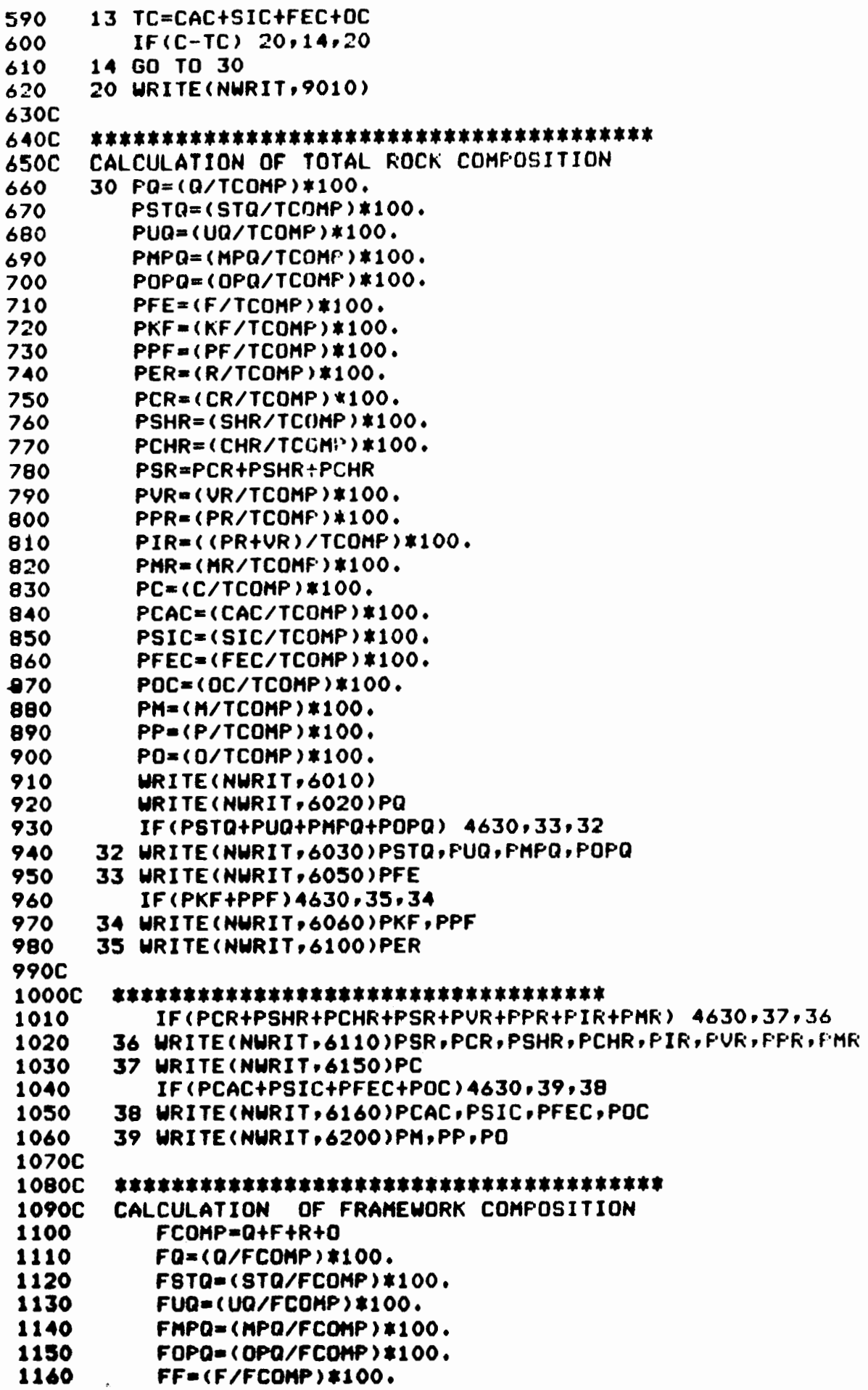




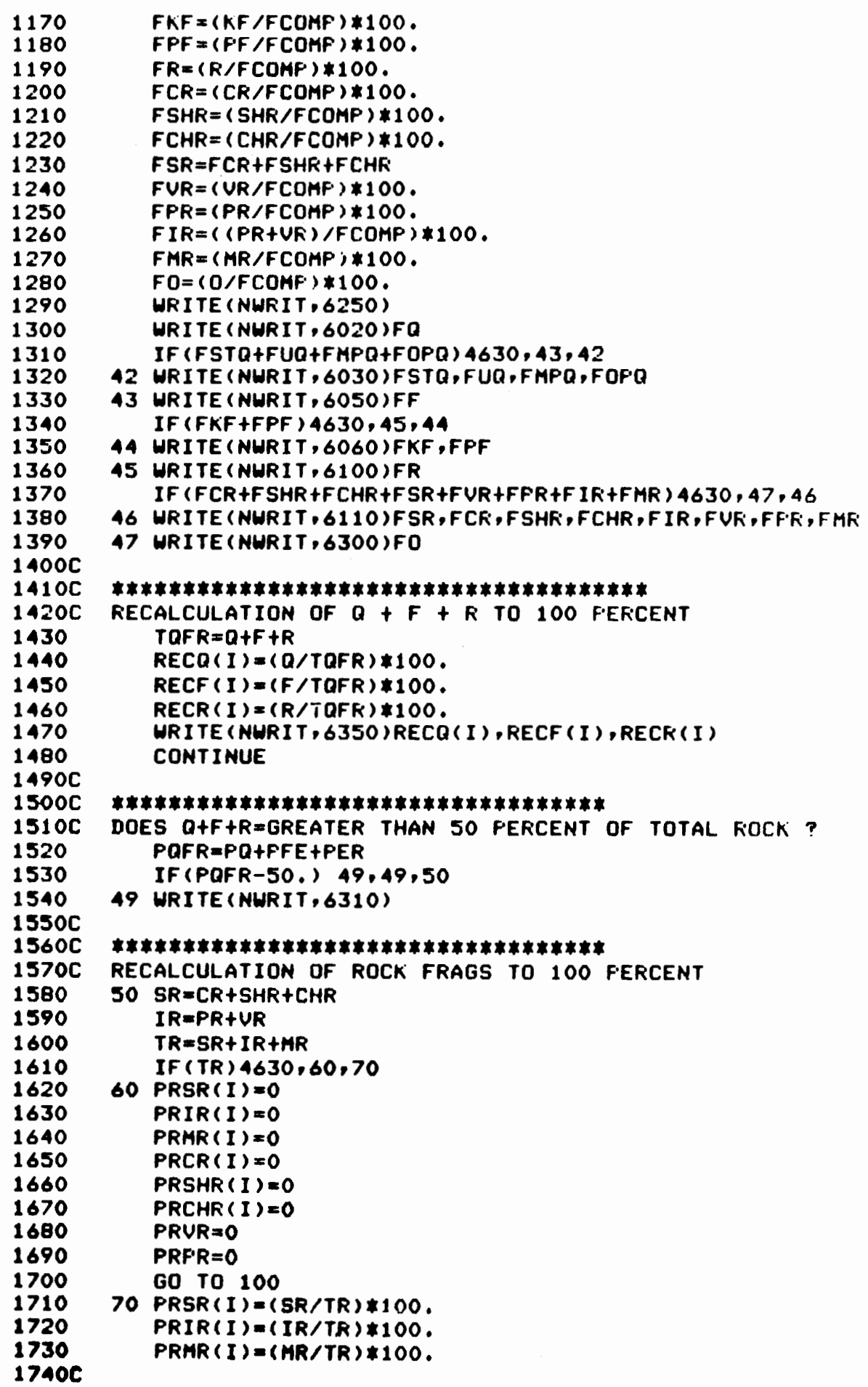




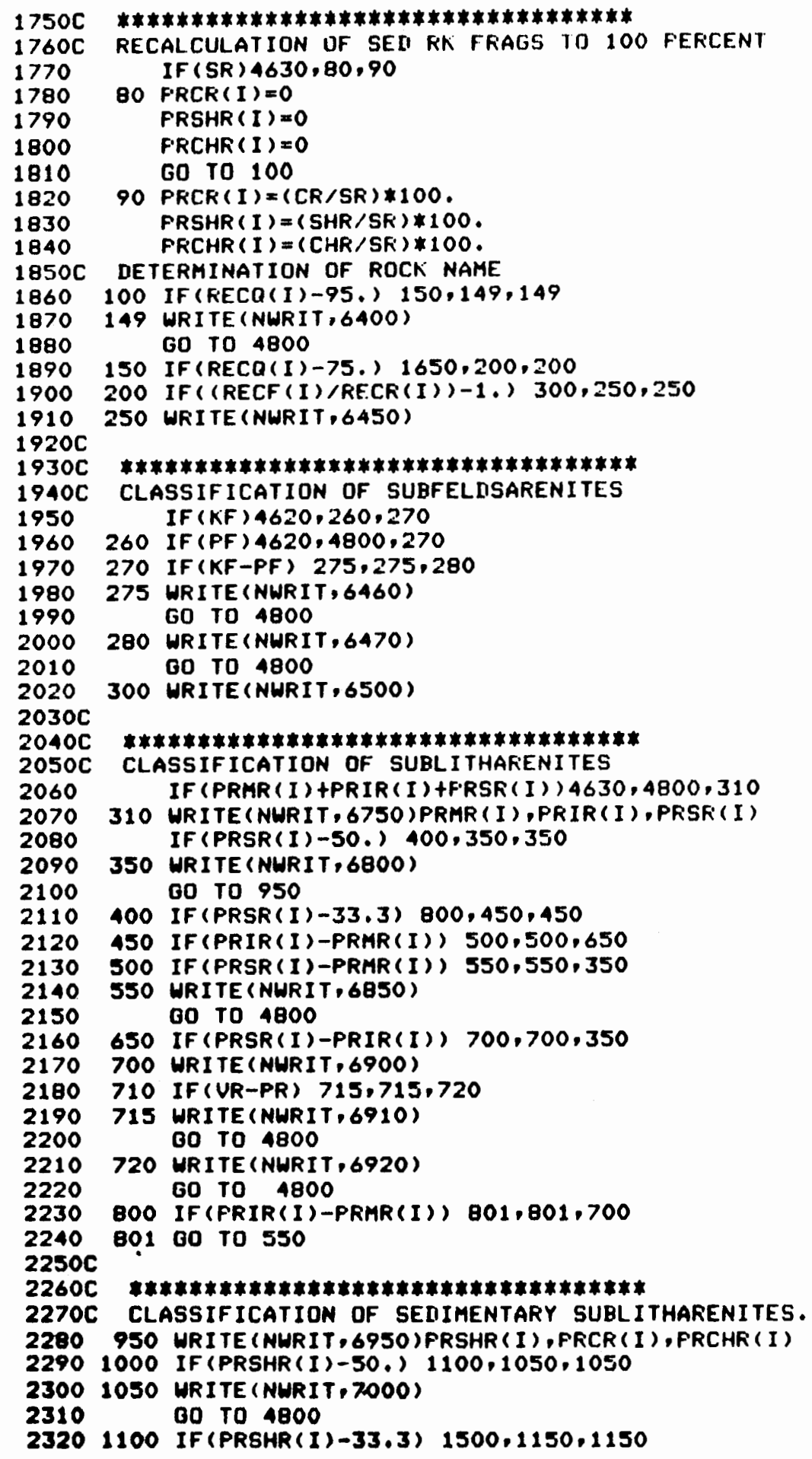




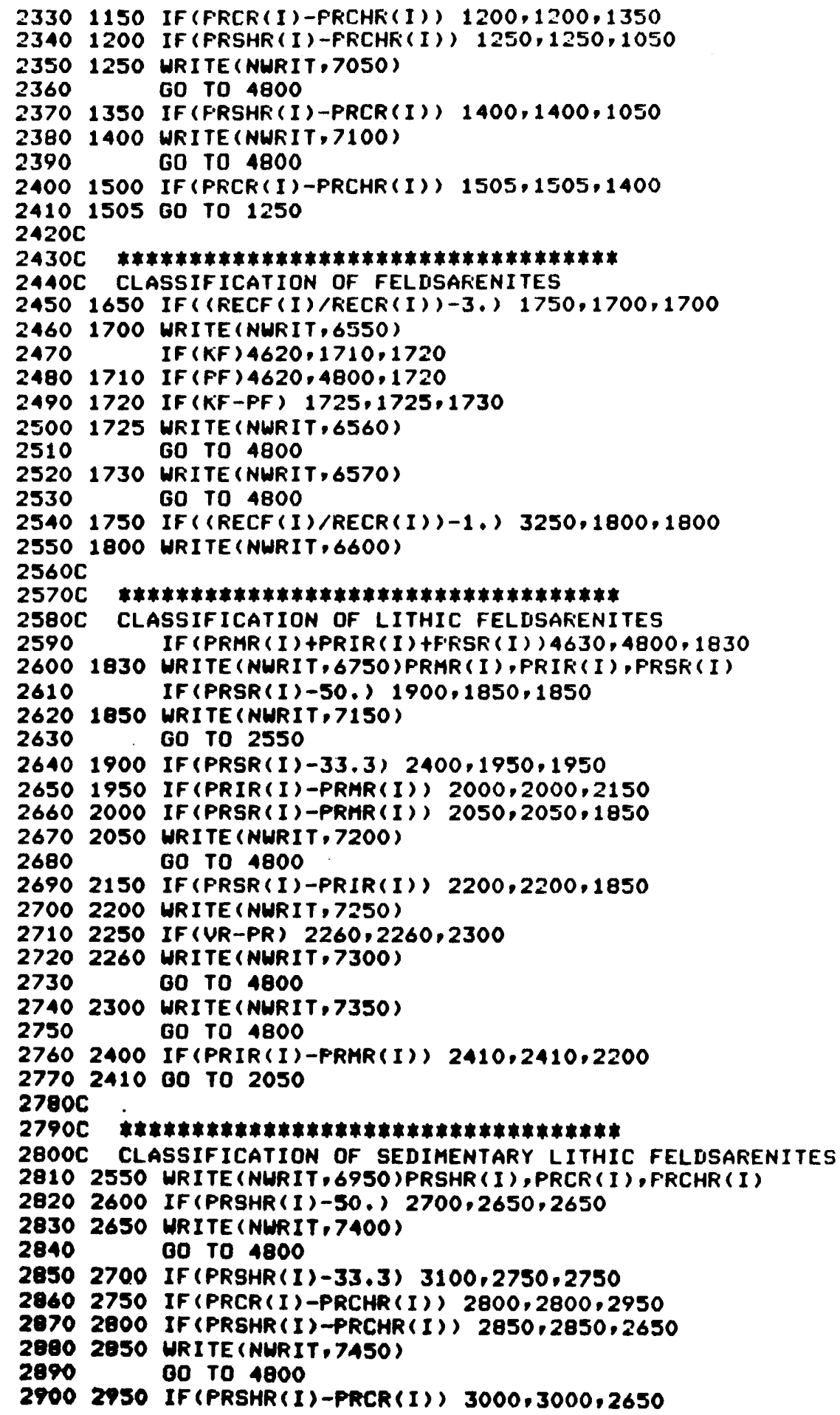




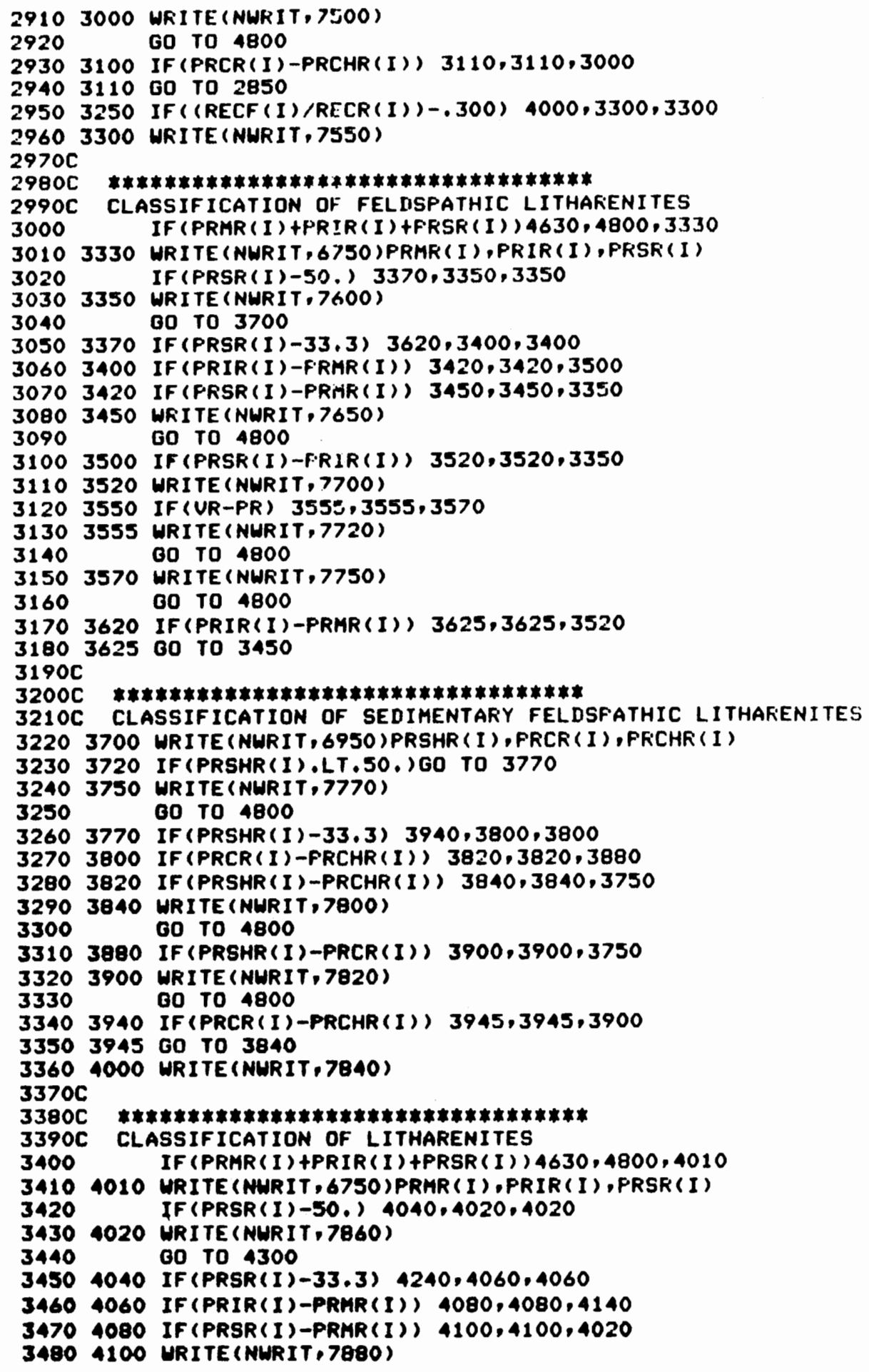




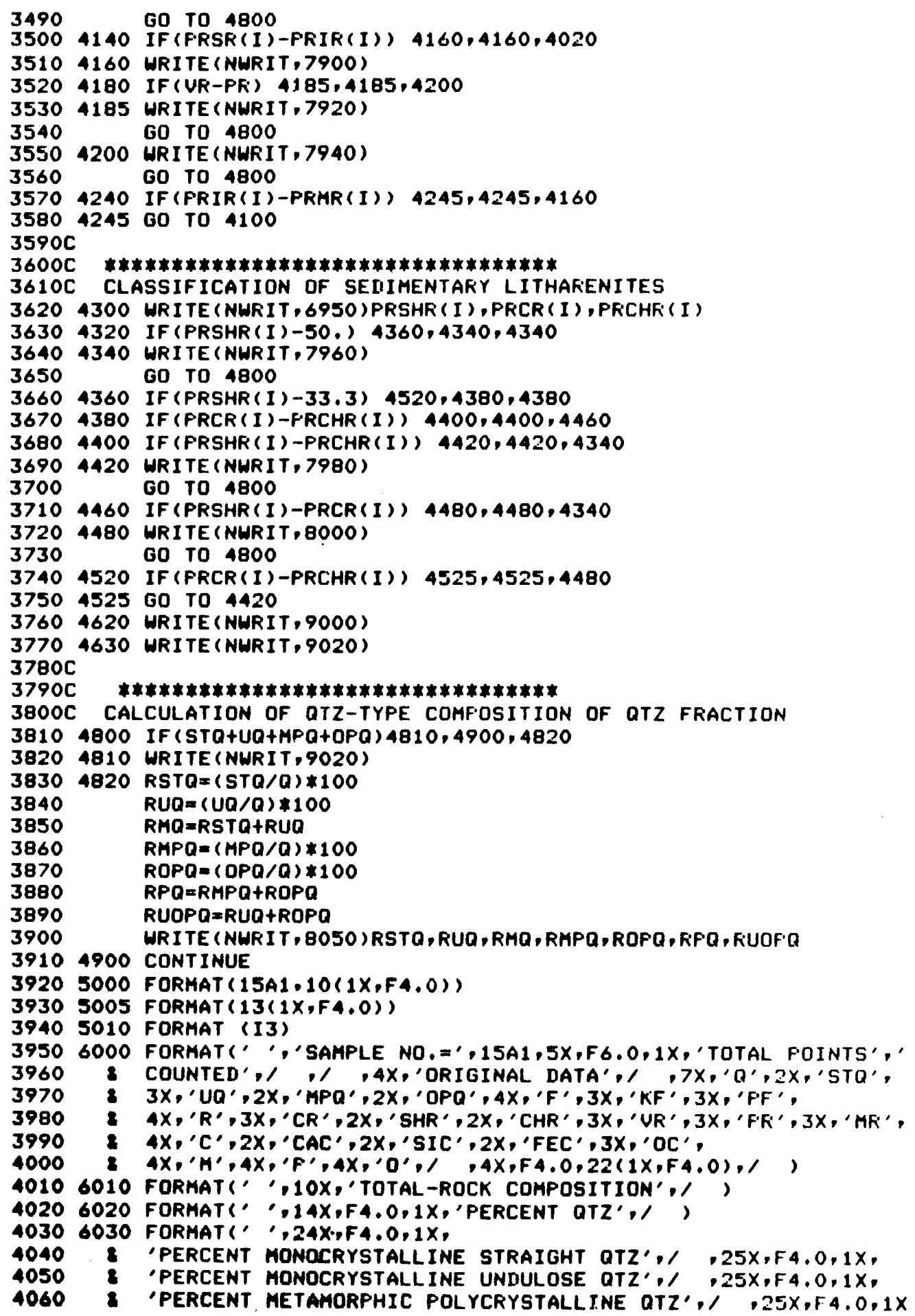




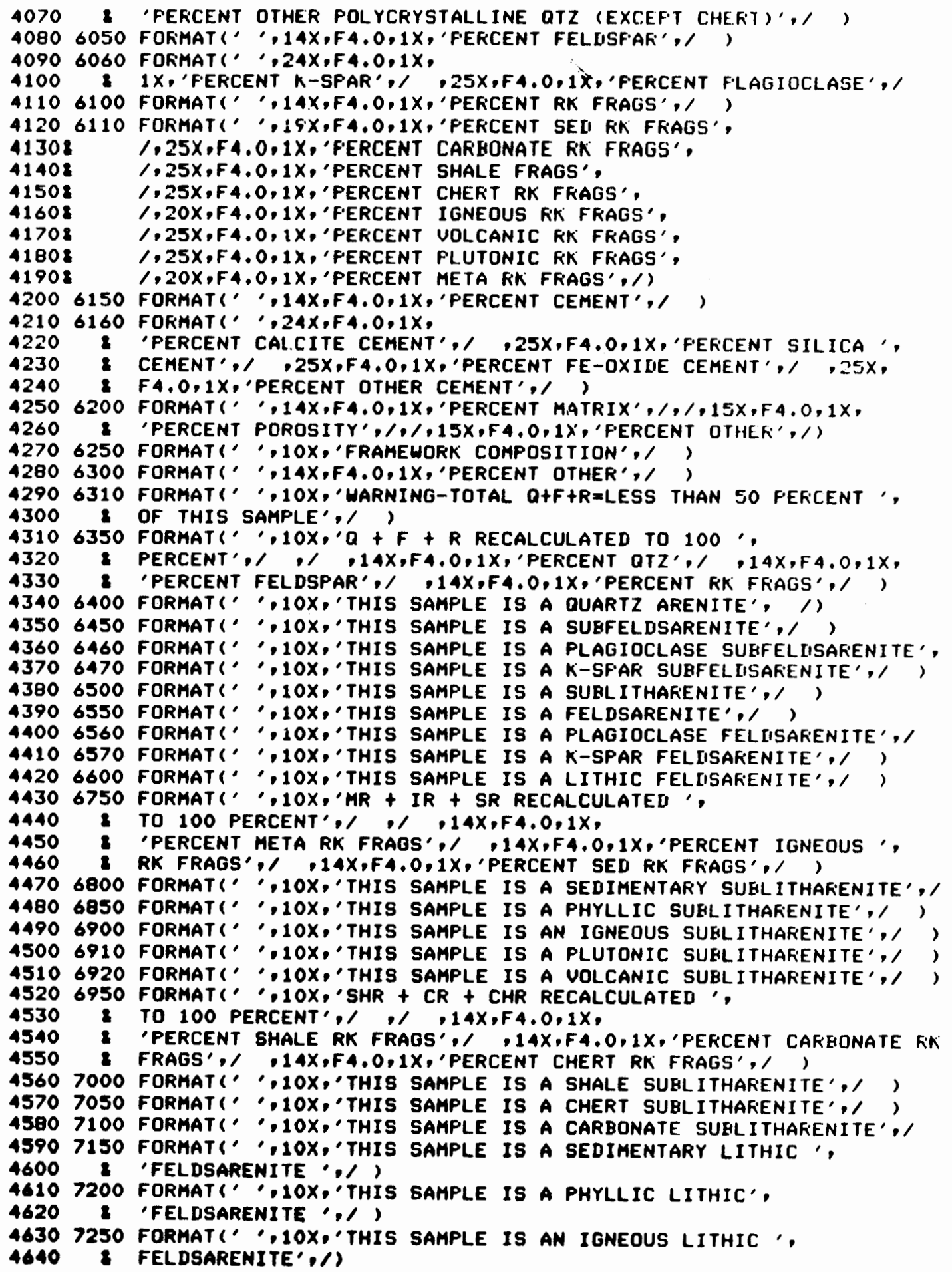




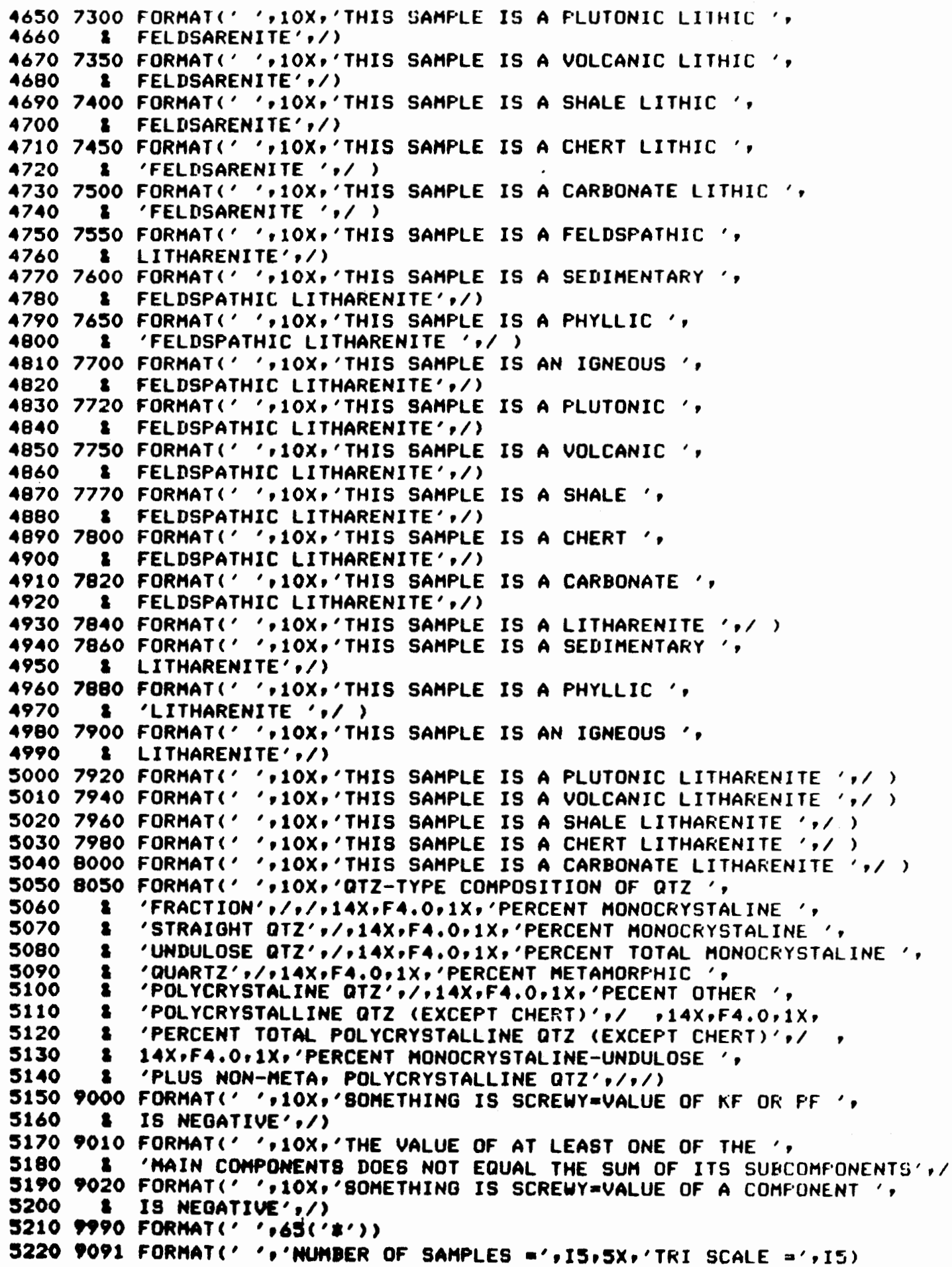




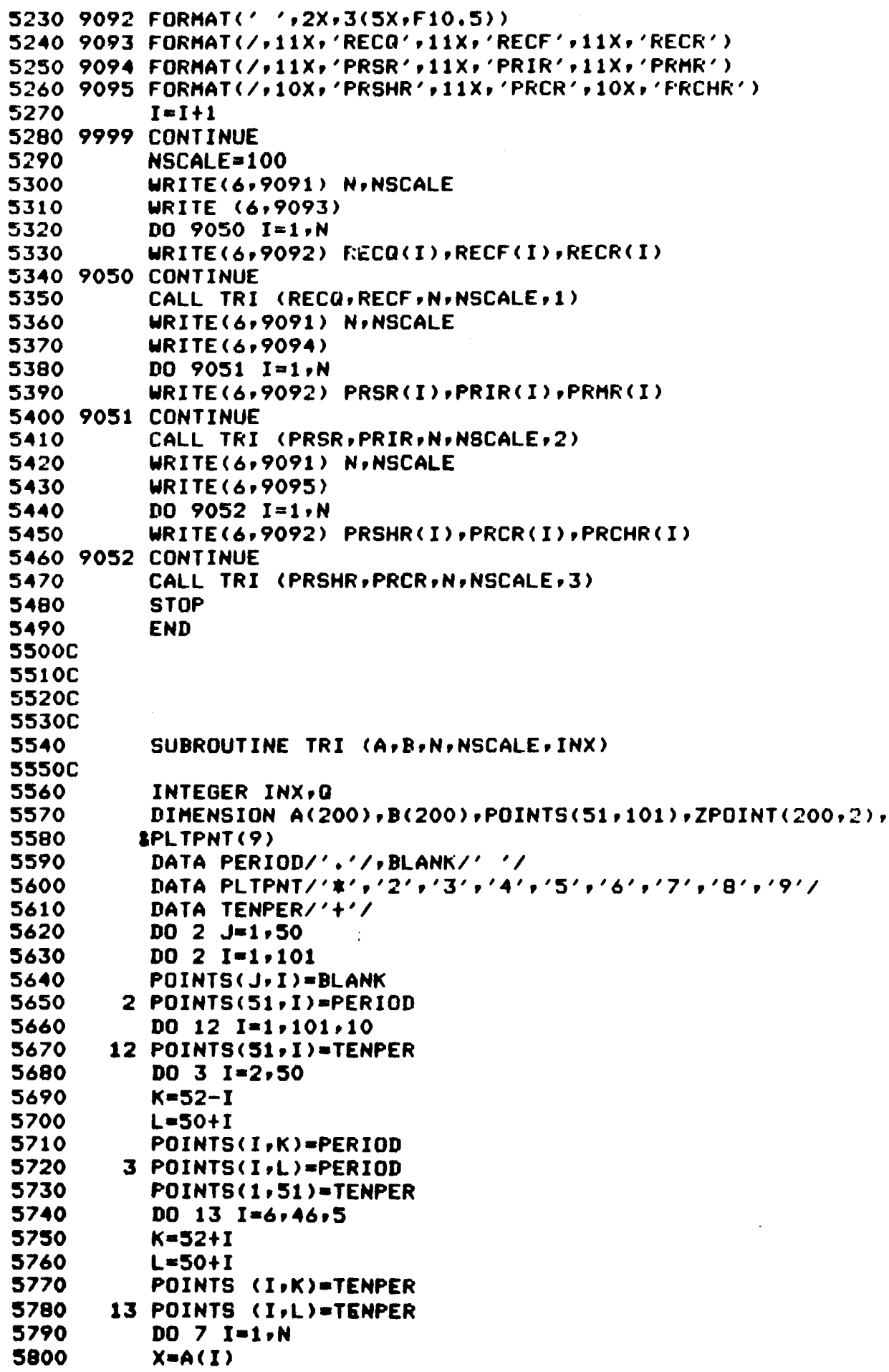




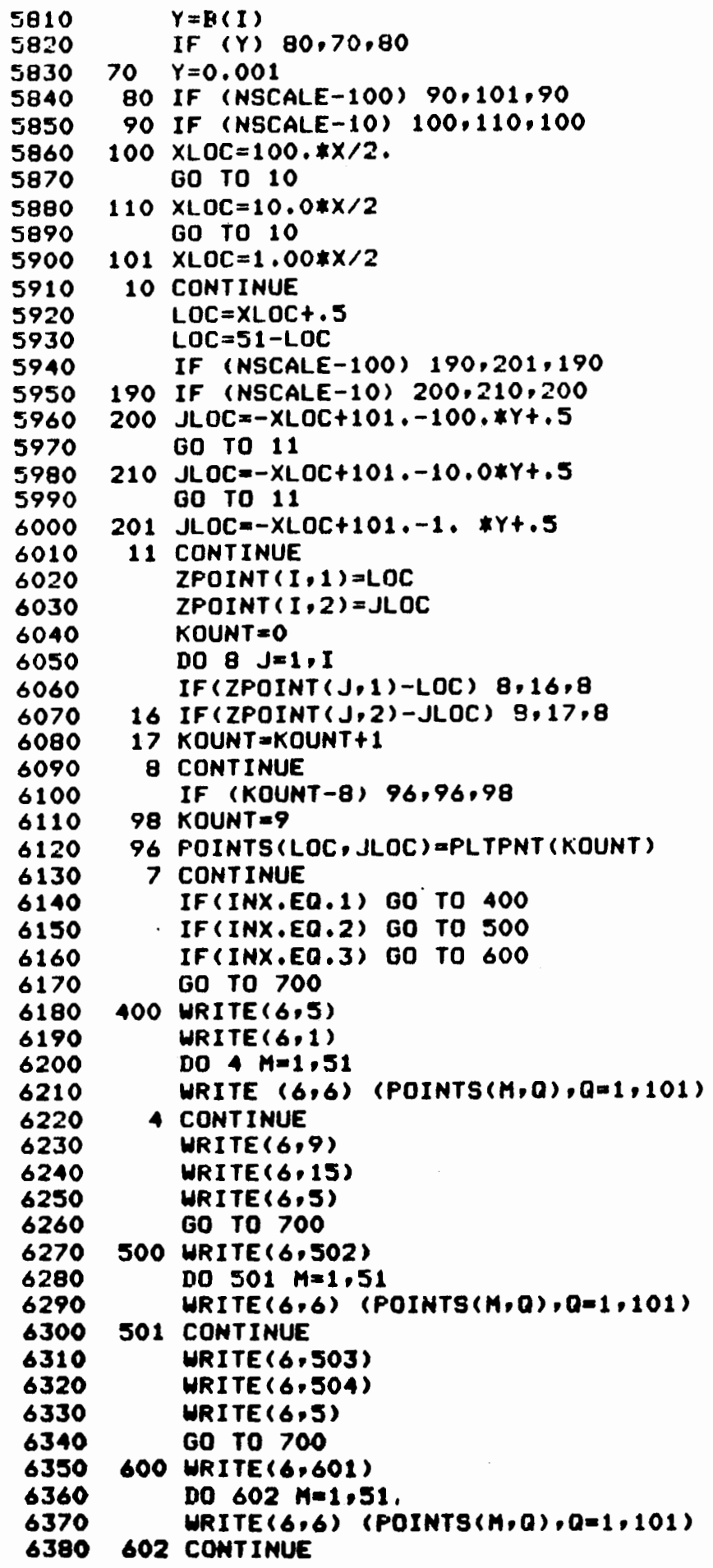


6390

6400

6410

6420

6430

6440

6450

6460

6470

6480

6490

6500

6510

6520

6530

6540

6550

6560
WRITE $(6,603)$

1 FORMAT(' ', 63X' 'QUARTZ')

5 FORMAT(' 1 ')

6 FORMAT (", 16X,101A1)

9 FORMAT(' ', 10X,'FELISP', 101X,'RKFRAG')

15 FORMAT(' ',9X⿰'

502 FORMAT(' ', $64 X_{1}$,'SEDRKF')

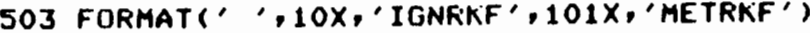

504 FORMAT(' ',9X,'(UOLC+PLUT)')

601 FORMAT(" ',64X,'SHLFKF')

603 FORMAT(', '10X,'CA RKF', $101 X^{\prime}$, 'CH RKF')

700 110 $701 \quad \mathrm{I}=1,51$

no $702 \quad M=1,101$

FOINTS $(I, M)=$ BL.ANK

702 CONTINUE

701 CONTINUE RETURN

END 


\section{APPENDIX B}

Areal Extent of Aerial Photo Mapping 


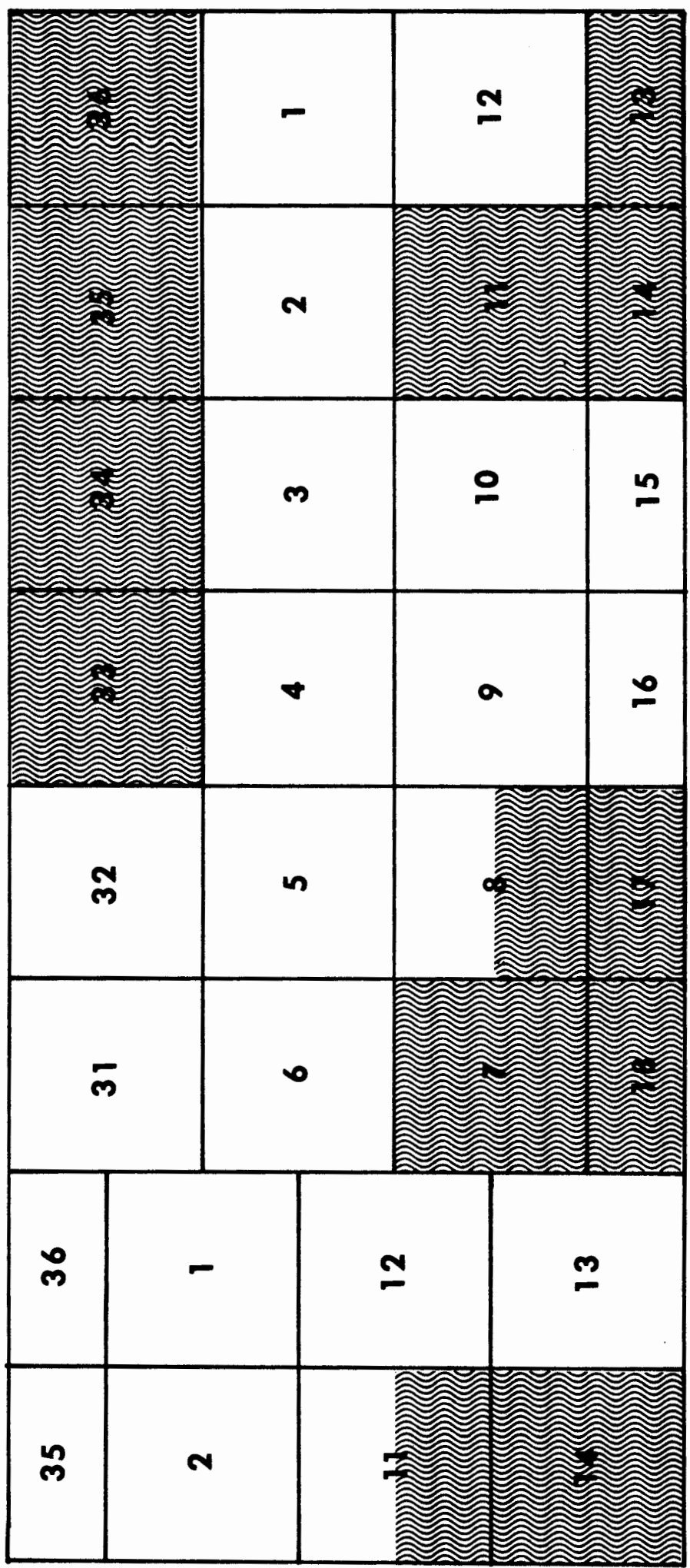

$\stackrel{0}{+1}$

도

"ृ

م

囟

n

d .

मำ

का

工 엉

30

O

官

ه.

$0+$

म्त

$\times 4$

(1) م

(1) 4

U

ט.

$\sigma$

40

다 옹

0

开

.

40

요

ฮั

$\times 0$

(1)

今

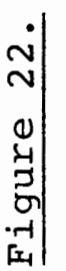

